\title{
Vaporization and Thermodynamics of Forsterite-Rich Olivine and some Implications for Silicate Atmospheres of Hot Rocky Exoplanets
}

\author{
Gustavo C. C. Costa $^{1}$, Nathan S. Jacobson ${ }^{1}$, Bruce Fegley Jr. ${ }^{2}$ \\ ${ }^{1}$ NASA Glenn Research Center, 21000 Brookpark Road, MS 106-1, Cleveland, OH, 44135, \\ USA \\ ${ }^{2}$ Planetary Chemistry Laboratory, McDonnell Center for the Space Sciences, Department of \\ Earth and Planetary Sciences, Washington University in St. Louis, Campus Box 1169, 1 \\ Brookings Dr, St. Louis, MO, 63130-4899, USA
}

*Corresponding Author. Tel: 216-433-8694. E-mail: gustavo.costa@nasa.gov (Gustavo C. C. Costa) 


\section{Abstract}

We describe an experimental and theoretical study of olivine $\left[\mathrm{Mg}_{2} \mathrm{SiO}_{4}(\mathrm{Fo})-\mathrm{Fe}_{2} \mathrm{SiO}_{4}(\mathrm{Fa})\right]$ vaporization. The vaporization behavior and thermodynamic properties of a fosterite-rich olivine $\left(\mathrm{Fo}_{95} \mathrm{Fa}_{5}\right)$ have been explored by high-temperature Knudsen effusion mass spectrometry (KEMS) from $1750-2250 \mathrm{~K}$. The gases observed (in order of decreasing partial pressure) are $\mathrm{Fe}, \mathrm{SiO}$, $\mathrm{Mg}, \mathrm{O}_{2}$ and $\mathrm{O}$. We measured the solidus temperature ( $\left.2050 \mathrm{~K}\right)$, partial pressures of individual gases, the total vapor pressure, and thermodynamic activities and partial molal enthalpies of $\mathrm{MgO}$, ' $\mathrm{FeO}$ ', and $\mathrm{SiO}_{2}$ for the $\mathrm{Fo}_{95} \mathrm{Fa}_{5}$ olivine. The results are compared to other measurements and models of the olivine system. Our experimental data show olivine vaporizes incongruently. We discuss this system both as a psuedo-binary of Fo-Fa and a psuedo-ternary of $\mathrm{MgO}$ - ' $\mathrm{FeO}$ '$\mathrm{SiO}_{2}$. Iron/magnesium molar ratios in the sample before $(\sim 0.05)$ and after $(\sim 0.04)$ vaporization are consistent with the small positive deviations from ideality of fayalite $(\gamma \sim 1.17)$ in olivine of the composition studied (e.g., Nafziger \& Muan 1967). Our data for olivine + melt confirm prior theoretical models predicting fractional vaporization of Fe relative to $\mathrm{Mg}$ from molten silicates (Cameron \& Fegley 1987, Schaefer \& Fegley 2009, Ito et al. 2015). If loss of silicate atmospheres occurs from hot rocky exoplanets with magma oceans the residual planet may be enriched in magnesium relative to iron.

\section{Introduction}

We studied vaporization of olivine $\left(\mathrm{Mg}_{\mathrm{x}} \mathrm{Fe}_{1-\mathrm{x}}\right)_{2} \mathrm{SiO}_{4}$ because it is one of the major silicate minerals that make up rocky planets in our solar system and presumably in extrasolar planetary systems (see below). The major gases produced by olivine vaporization ( $\mathrm{Fe}, \mathrm{Mg}, \mathrm{SiO}, \mathrm{O}_{2}$, and $\mathrm{O}$ ) are calculated to be abundant over wide $\mathrm{P}, \mathrm{T}$ ranges in the atmospheres of hot, rocky extrasolar planets such as CoRoT-7b (e.g., Schaefer \& Fegley 2009, Ito et al. 2015). One purpose of our work is to provide reliable experimental vapor pressure data for olivine that can be used to test published calculations and guide future experimental work and spectroscopic observations.

Olivine contains the three most abundant elements $(\mathrm{Mg}, \mathrm{Si}, \mathrm{Fe})$ in solar composition material that combine with oxygen to form rock (Lodders 2003). The atomic abundances of $\mathrm{Mg}, \mathrm{Si}$, and $\mathrm{Fe}$ are similar to one another (within $20 \%$ ) and are $1.03 \times 10^{6}(\mathrm{Mg}), 1.00 \times 10^{6}(\mathrm{Si})$, and $0.848 \times$ $10^{6}(\mathrm{Fe})$ on the cosmochemical scale. All other elements that combine with oxygen to form rock 
are significantly less abundant, e.g., $\mathrm{Al}\left(0.0846 \times 10^{6}\right), \mathrm{Ca}\left(0.0604 \times 10^{6}\right), \mathrm{Na}\left(0.0577 \times 10^{6}\right), \mathrm{Ni}$ $\left(0.049 \times 10^{6}\right), \mathrm{Mn}\left(0.00922 \times 10^{6}\right), \mathrm{K}\left(0.00376 \times 10^{6}\right)$, and $\mathrm{Ti}\left(0.00247 \times 10^{6}\right)$. Spectroscopic studies of main sequence $\mathrm{F}$ and $\mathrm{G}$ stars with near-solar metallicity show constant ratios of $\mathrm{Fe}$, Mg, and Si to one another (section 3.4.7 in Lodders, Palme \& Gail 2009). Consequently olivine (and its high pressure polymorphs) is probably the major mineral in rocky exoplanets.

Magnesian (forsterite - rich) olivine with an average composition of $\left(\mathrm{Mg}_{0.9} \mathrm{Fe}_{0.1}\right)_{2} \mathrm{SiO}_{4}$ is the dominant mineral in peridotite; the rock comprising Earth's upper mantle (Palme \& O'Neill 2014). Olivine is a solid solution between the end members forsterite $\left(\mathrm{Fo}: \mathrm{Mg}_{2} \mathrm{SiO}_{4}\right)$ and fayalite ( $\mathrm{Fa}: \mathrm{Fe}_{2} \mathrm{SiO}_{4}$ ) with continuous variation of the solidus and liquidus curves from the melting point of the lower melting component (Fayalite $1490 \mathrm{~K}, \Delta_{\text {fus }} \mathrm{H}^{\circ}=89.3 \pm 1.1 \mathrm{~kJ} \mathrm{~mol}^{-1}$ ) to the melting point of the higher melting component (Forsterite $2163 \mathrm{~K}, \Delta_{\text {fus }} \mathrm{H}^{\circ}=102.8 \pm 5 \mathrm{~kJ} \mathrm{~mol}^{-1}$ ); in other words a cigar - shaped phase diagram (Bowen \& Schairer 1935, see Figure 9). Melting begins at the solidus temperature and is completed at the liquidus temperature. Throughout this paper we use the terms "melting point" and "solidus" interchangeably.

Forsterite-rich olivine is present in the Earth's crust as an important constituent of mafic and ultramafic igneous rocks and also is found in thermally metamorphosed, dolomitic limestones (Liebau 2012). Moreover, it has important technological applications in the ceramic and metallurgic industries, and in catalysis given its chemical and structural properties (Swierczynski, Courson et al. 2006). Olivine is also present in extra-terrestrial bodies such as the Moon, Mars, asteroids, meteorites, comets, interplanetary dust particles and circumstellar dust shells (Keil et al. 1970, Hoefen et al. 2003, Cruikshank and Hartmann 1984, Nguyen and Zinner 2004, Campins and Ryan 1989, Bradley et al. 1992, Woolf and Ney 1969).

Olivine is an orthosilicate mineral and naturally occurring forsterite-rich olivine adopts an orthorhombic (space group Pbnm) symmetry (Liebau 2012). In this structure $\left[\mathrm{SiO}_{4}\right]$ tetrahedra are isolated and cross-linked by chains of edge-sharing, distorted octahedra $\left[\mathrm{MO}_{6}\right]$ occupied by divalent cations (M) such as $\mathrm{Mg}^{2+}$ and $\mathrm{Fe}^{2+}$ (Liebau 2012). Minor amounts of other divalent cations (e.g. $\mathrm{Ca}^{2+}, \mathrm{Mn}^{2+}$ and $\mathrm{Ni}^{2+}$ ) can also occupy the octahedra $\left[\mathrm{MO}_{6}\right]$ crystallographic sites and are commonly found in natural olivines (Liebau 2012). As noted above $\mathrm{Ca}, \mathrm{Mn}$, and $\mathrm{Ni}$ are significantly less abundant than $\mathrm{Mg}$ or $\mathrm{Fe}$ and to good first approximation naturally occurring olivine is a binary solid solution between forsterite and fayalite. The $\mathrm{Mg}$ and Fe content in the solid solution of olivine and minor amounts of other divalent cations in its structure, which are 
common in natural olivine, are expected to affect vaporization and its thermodynamic properties by introducing activation energy for vaporization, leading to rate control by diffusion through different bonding strength and atomic structural configuration, affecting surface energy, the free energy of desorption, and the activation free energy for surface diffusion. (Hirth 1967, Navrotsky 1978) Thus, it is important that the sample is fully structurally and chemically characterized before and after vaporization experiments (see below) in order to understand at the microscopic atomic level possible discrepancies between different experiments, and experimental and theoretical thermodynamic results.

Given the importance of the $\mathrm{MgO}$ - ' $\mathrm{FeO}$ '- $\mathrm{SiO}_{2}$ system, there are a very large number of experimental and theoretical studies of its thermodynamics and phase relationships. Strictly speaking (as noted by Bowen \& Schairer 1935) the $\mathrm{MgO}-{ }^{\circ} \mathrm{FeO}$ ' - $\mathrm{SiO}_{2}$ system is pseudoternary (and the $\mathrm{FeO}-\mathrm{SiO}_{2}$ subsystem is pseudo-binary) because there is always a small amount of ferric iron present in the liquid in equilibrium with $\mathrm{FeO}$-bearing pyroxenes and olivine, which melt incongruently with separation of iron metal and silica. For example, Bowen \& Schairer (1932) showed this for melting of pure fayalite and Stebbins \& Carmichael (1984) confirmed their results; the melting reaction is

$$
\begin{gathered}
\mathrm{Fe}_{2} \mathrm{SiO}_{4}(\text { fayalite })=0.9620 \mathrm{Fe}_{2} \mathrm{SiO}_{4}(\mathrm{liq})+0.0253 \mathrm{Fe}_{2} \mathrm{O}_{3} \text { (liq) } \\
+0.0380 \mathrm{SiO}_{2}(\mathrm{liq})+0.0253 \mathrm{Fe} \text { (metal) }
\end{gathered}
$$

The molar ratio of $\mathrm{Fe}^{3+} / \mathrm{Fe}^{2+}$ is $~ 0.026$ in the melt. However the $\mathrm{Mg}_{2} \mathrm{SiO}_{4}-\mathrm{Fe}_{2} \mathrm{SiO}_{4}$ system has always been treated as a binary system because ferric iron, although present, is only a minor component. We will return to this point later in the discussion.

The forsterite - fayalite solid solution has small positive deviations from ideality. There is no statistically significant excess entropy of mixing (Dachs \& Geiger 2007), so a symmetric regular solution model with one parameter, as recommended by many groups (e.g., Dachs \& Geiger 2007, von Seckendorff \& O’Neill 1993, Wiser \& Wood 1991, Kitayama \& Katsura 1968, Larimer 1968, Nafziger \& Muan 1967) is sufficient for describing the small amounts of nonideality. The $\mathrm{Mg}^{2+}$ and $\mathrm{Fe}^{2+}$ cations are distributed on the M1 and M2 octahedral sites in olivine (Muan 1967, Nafziger \& Muan 1967) so equations for activity coefficients and exchange equilibria of forsterite and fayalite are written in terms of one half formula unit, e.g. $\mathrm{MgSi}_{0.5} \mathrm{O}_{2}$ $\left(=1 / 2 \mathrm{Mg}_{2} \mathrm{SiO}_{4}\right)$ and $\mathrm{FeSi}_{0.5} \mathrm{O}_{2}\left(=1 / 2 \mathrm{Fe}_{2} \mathrm{SiO}_{4}\right)$. The activities of $\mathrm{MgSi}_{0.5} \mathrm{O}_{2}$ and $\mathrm{FeSi}_{0.5} \mathrm{O}_{2}$ have been determined by several different methods including Fe-Mg partitioning between olivine and 
orthopyroxene and Fe-Mg partitioning between olivine and coexisting magnesiowüstites. In their classic paper on this system, Nafzinger and Muan (Nafziger and Muan 1967) determine activities and phase boundaries by several equilibration methods. There are several measurements of $\mathrm{a}(\mathrm{FeO})$ and in some cases, calculation of $\mathrm{a}(\mathrm{MgO})$ from the Gibbs-Duhem equation. (Kojima, Inouye et al. 1969, Sakawa, Whiteway et al. 1976, Plante, Hastie et al. 1992) In all cases, a positive deviation from ideality is reported for a $(\mathrm{FeO})$. Plante et al. used a KEMS method and their Knudsen cell had an iridium liner in a tungsten cup. Measurements were taken over the entire range of compositions from fayalite to forsterite at $1973 \mathrm{~K}$ in the molten phase. KEMS measurements of olivine were reported in another study (Piacente, Matousek et al. 1975). Several different Knudsen cells of zirconia, thoria, and rhenium were used in the temperature range $1678-1925 \mathrm{~K}$ and rhenium was found to be the most inert. The observed vapor species were $\mathrm{Fe}, \mathrm{SiO}, \mathrm{Mg}$, and $\mathrm{O}_{2}$ and partial pressures were reported as a function of temperature.

The calculated pseudo-binary (Fo-Fa) phase diagram is shown in Fig. 1(a). This shows the classical 'cigar shape', which is indicative of a near-ideal solution. Fig. 1(b) is the calculated phase diagram for the pseudo-binary $\mathrm{MgO}$ - ${ }^{\mathrm{FeO}}$ '- $\mathrm{SiO}_{2}$ system at $1400 \mathrm{~K}$ (Fabrichnaya 1998, Fabrichnaya 2000, Andersson, Helander et al. 2002). The MgO-'FeO'-SiO 2 system has been modeled by several investigators. Saxena (Saxena, Chatterjee et al. 1993) first described the olivine solution as a regular solution with a single, temperature independent solution parameter. Fabrichnaya modeled the entire $\mathrm{MgO}-{ }^{\prime} \mathrm{FeO}$ '- $\mathrm{SiO}_{2}$ system with a sublattice model for the solid phases and ionic model for the liquid phase (Fabrichnaya 1998, Fabrichnaya 2000). This system has also been modeled with a modification of the quasi-chemical model (Wu, Eriksson et al. 1993, Jung, Decterov et al. 2004).

The vaporization and condensation kinetics of olivine are important to understand processes in the early solar nebula and have been studied by Nagahara and colleagues. (Nagahara, Kushiro et al. 1988, Nagahara, Kushiro et al. 1994, Ozawa \& Nagahara 2000) The results indicate the vaporization of olivine is complex. Their results suggest that forsterite and fayalite vaporize congruently (i.e. composition of the starting material remains the same). Condensates consist of olivine, pyroxene, silica and iron, suggesting that the condensation occurs with decomposition. 
In this study, we examine near-equilibrium vaporization of olivine in iridium cells with Knudsen effusion mass spectrometry (KEMS). Initial measurements were taken below, through the melting point (solidus) into the two phase region (olivine + liquid), and above the liquidus of the olivine polycrystalline sample. We report the pressures of each vapor constituent over a $\mathrm{FO}_{95} \mathrm{Fa}_{5}$ composition as a function of temperature. Samples were characterized with particular care before and after vaporization. Thermodynamic data are interpreted as both a pseudo-binary and pseudo-ternary. The reported vapor pressures are used to calculate thermodynamic activities, which are compared to those from prior measurements and models of this system and related systems. We conclude with a discussion of implications of these measurements for the silicate atmospheres of the hot rocky exoplanets.

\section{Experimental Methods}

\subsection{Materials}

Natural olivine used in this study is from one of the dunite deposits on the west coast of Norway and was provided by Miller \& Co., Chicago, IL. We used a natural material in this study to measure and understand the mineral olvine. As discussed in the Supplementary Material, we were able to purify this natural olivine to high level and obtain reliable thermodynamic data. The as-received powder sample was annealed in a vacuum furnace at $1700 \mathrm{~K}$ for $10 \mathrm{~h}$ to eliminate the impurities. After the impurities were removed by heat treatment in vacuum, this sample was analyzed by KEMS below and above its melting point (solidus).

\subsection{Knudsen Effusion Mass Spectrometry (KEMS)}

Knudsen Effusion Mass Spectrometry was performed using a modified Nuclide-type 12-HT-90 (Nuclide/MAAS/PATCO, formerly of State College, PA) mass spectrometer. The equipment and experimental procedures have been described previously (Drowart and Goldfinger 1967, Kato 1993, Copland and Jacobson 2010). The instrument consists of four differentially pumped chambers-Knudsen cell chamber with furnace, ionizer chamber, magnet drift tube, and analyzer chamber. The instrument schematic is shown in Fig. 2. 
After some experimentation (discussed in Supplementary Material), an iridium cell was selected for this study. This was placed in a graphite support, as iridium is known not to form carbides (Lee and Worrell 1989). This assembly was supported by a tripod and restively heated with a tantalum heating element in a repeating 'hair-pin' shape. The tantalum heating element and the cell were enclosed in a dense heat shield pack consisting of four inner layers of reflective tungsten and four outer layers of molybdenum. Temperatures above $2000 \mathrm{~K}$ were reached with this configuration and were measured with a disappearing-filament-type pyrometer (Microtherm, Pyrometer Instrument Co., Windsor, NJ). Calibration of the instrument and the pyrometer were performed prior to each experiment with an ITS-90 gold standard (Preston-Thomas 1990) in a graphite cell, either via melting or adjusting the temperature correction for the tabulated enthalpy of vaporization (Hultgren, Desai et al. 1973). This procedure allowed temperature measurements to within $\pm 3 \mathrm{~K}$.

The vapor effusing from the cell is directed into the mass spectrometer. A moveable shutter located between the Knudsen chamber and ionization chamber was used to subtract the background contribution from the total signal. For most of the species studied, the background was very small in our instrument. However for $\mathrm{SiO}(\mathrm{g})$ at mass-to-charge ratio of $44, \mathrm{CO}_{2}(\mathrm{~g})$ gave a significant background and the shutter was essential for measurement. In addition, a liquid nitrogen cold finger placed into the ionization chamber was used to condense and reduce the background $\mathrm{CO}_{2}$ gas.

The ionization chamber is located directly above the Knudsen cell. Ionization is accomplished with 26 or $16.5 \mathrm{eV}$ electrons at a total emission current of $2 \mathrm{~mA}$. The molecular beam from the Knudsen cell, ionizing electron beam, and resultant ion beam are all mutually perpendicular in our instrument. The partial vapor pressures of the ionic species of the samples were calculated through the following relationship (Drowart and Goldfinger 1967, Copland and Jacobson 2010).

$$
P_{i}=\frac{k I_{i} T}{\sigma_{i}(E)}
$$

where $P_{i}$ (bar) is the partial pressure of the species inside of the cell at absolute temperature $T, k$ is the instrument calibration constant $\left(\mathrm{bar} \cdot \mathrm{m}^{2} \cdot \mathrm{cps}^{-1} \cdot \mathrm{K}^{-1}\right)$ determined from the triple-point plateau of gold at $1337.3 \mathrm{~K}, I_{i}$ (counts per second, cps) is the ion intensity of the species and $\sigma_{i}\left(\mathrm{~m}^{2}\right)$ is 
the ionization cross section of the species taken from Mann's tabulation of atoms (Mann 1967) which is a function of ionizing electron energy, E. Mann's values were corrected for the lower electron energies used with the Bonnell Bell Distribution code (Drowart, Chatillon, et al. 2005). For molecules, the atomic cross sections are summed and multiplied by 0.75 (Stolyarova, Semenov et al. 1994). In order to measure both atomic and diatomic oxygen, ionizing electrons with an energy of $16.5 \mathrm{eV}$ were used. This was derived from $12.1 \mathrm{eV}$ (First ionization potential of diatomic oxygen (Field and Franklin 2013)) and 5 eV (bond energy of oxygen double bond (Pauling 1960)). So as long as the ionizing electron energy is less than $17 \mathrm{eV}$, we will ionize diatomic oxygen, but not fragment it.

The ion beam is focused with a series of plates near $10 \mathrm{kV}$ and directed into a magnetic analyzer. The proper mass-to-charge ratio was set by adjusting the magnetic field. The ions were detected with a 20 dynode electron multiplier in a counting configuration. The use of a nonmagnetic ionizer, magnetic analyzer, and ion counting should yield a calibration constant (equation 2) that is independent of mass number.

The instrument was computer controlled and the data acquired with NASA Glenn software (Copland, Auping et al. 2013). Initially a full mass scan was conducted to determine the major vaporizing species. Species were further identified from their mass-to-charge ratio and appearance potentials. Individual peaks were scanned six times for adequate statistics.

The component thermodynamic activities in the olivine system are calculated through the measurements of the vapor pressures of the species in equilibria with olivine (see the chemical equations below). For the activity calculations, it is assumed that the olivine system is a three component system of 'FeO' (wüstite), $\mathrm{MgO}$ (periclase), $\mathrm{SiO}_{2}$ (high cristobalite).

$$
\begin{gathered}
\mathrm{FeO}(\text { olivine })=\mathrm{Fe}(\mathrm{g})+1 / 2 \mathrm{O}_{2}(\mathrm{~g}) \\
\mathrm{MgO}(\text { olivine })=\mathrm{Mg}(\mathrm{g})+1 / 2 \mathrm{O}_{2}(\mathrm{~g}) \\
\mathrm{SiO}_{2}(\text { olivine })=\mathrm{SiO}(\mathrm{g})+1 / 2 \mathrm{O}_{2}(\mathrm{~g})
\end{gathered}
$$

Taking as an example $\mathrm{SiO}_{2}$. The equilibrium constant of this reaction can be written as given below where $f(i)$ is the fugacity of species $i$ : 


$$
K=\frac{f(\mathrm{SiO}, \mathrm{soln})\left[f\left(\mathrm{O}_{2}, \text { soln }\right)\right]^{1 / 2}}{a\left(\mathrm{SiO}_{2}\right)}
$$

This can be compared to the calculated value for pure ' $\mathrm{SiO}_{2}$ ':

$$
K=f^{o}(\mathrm{SiO})\left[f^{o}\left(\mathrm{O}_{2}\right)\right]^{1 / 2}
$$

Equating these two expressions and assuming for these low pressures, partial pressure is equal to fugacity, leads to:

$$
a\left(\mathrm{SiO}_{2}\right)=\frac{P(\mathrm{SiO}, \mathrm{soln})\left[P\left(\mathrm{O}_{2}, \mathrm{soln}\right)\right]^{1 / 2}}{P^{o}(\mathrm{SiO})\left[P^{o}\left(\mathrm{O}_{2}\right)\right]^{1 / 2}}=\frac{\text { Keq }, \text { soln }}{\text { Keq, pure }}
$$

Similar expressions can be derived for each component oxide. The advantage of this procedure is that the instrument constant, $k$, and ionization cross section, $\sigma_{i}(E)$, cancel and hence this source of error is eliminated. However, it is essential to mass spectrometrically measure the equilibrium constants for the pure materials as part of the study. This is the standard method for measuring activities in oxide solutions. (Stolyarova, Semenov et al. 1994, Copland and Jacobson 2001) For $\mathrm{MgO}$ and $\mathrm{SiO}_{2}$, it was possible to measure both the metal containing species and oxygen. Since stoichiometric $\mathrm{FeO}$ does not exist, we used Fe-rich $\mathrm{FeO}$. Wüstite $(\mathrm{FeO})$ coexists with $\mathrm{Fe}$ at this Fe-rich boundary compositions (Wriedt 1991) which allowed the KEMS measurements of the partial vapor pressures of $\mathrm{Fe}(\mathrm{g})$. This resulted in oxygen pressures below the instrument's levels of detection. Thus oxygen pressures were calculated from their stoichiometric relationship to the measured partial pressure of $\mathrm{Fe}(\mathrm{g})$. The dependence of the $\log$ of activity on inverse temperature gave the partial molar enthalpy for each component.

We used a single Knudsen cell furnace (Copland and Jacobson 2010) configuration, which required a different run for each reference material and the solid solution. Before each run, a calibration run was conducted with $\mathrm{Au}$, to determine the calibration instrument constant $k$ (equation (2)). We found the calibration constant to be constant between runs. 


\section{Results}

\subsection{Elemental and Phase Composition of the Samples}

The as-received olivine sample contained the secondary phases enstatite $(6.4 \pm 0.1 \%)$, clinochlore $(3.5 \pm 0.2 \%)$, sapphirine $(0.80 \pm 0.06 \%)$ and quartz $(0.79 \pm 0.04 \%)$ as impurities (Supplementary Material, Figure S1). This sample was heat treated at $1700 \mathrm{~K}$ for $10 \mathrm{~h}$ in vacuum to eliminate the impurities and later it was used in the KEMS vaporization experiments. Powder X-ray diffractograms (Supplementary Material) of the samples before and after the KEMS experiments performed below the melting point (solidus) of olivine confirm formation of a single crystalline phase in these samples. However, $15.1 \pm 0.3 \%$ protoenstatite was found in the sample heated above the solidus. The lattice parameters of the olivine are consistent with pure forsterite but electron probe microanalysis found trace amounts of $\mathrm{FeO}$ that correspond to $\mathrm{Fo}_{99.8} \mathrm{Fa}_{0.2}$ composition for the olivine and $\mathrm{En}_{99.8} \mathrm{Fs}_{0.2}$ for the pyroxene. The crystallite sizes calculated using a whole pattern fitting procedure (Rietveld refinement) of the sample diminished from $453 \pm 8$ $\mathrm{nm}$ to $329 \pm 7 \mathrm{~nm}$ after the KEMS experiment (below melting point or solidus). Powder X-ray diffractograms of the reference samples $\mathrm{FeO} / \mathrm{Fe}, \mathrm{MgO}$ and $\mathrm{SiO}_{2}$ after the KEMS experiments confirmed that they are single crystalline phases. The chemical composition of the samples before and after KEMS that were measured by inductively coupled plasma - optical emission spectroscopy (ICP-OES) and electron probe microanalysis (EPMA) is given in Table 1. The chemical composition of the samples in Table 1 is given for the contents of elements, oxides, and fosterite/fayalite since olivine constituents have different terminologies in different fields of science. Before and after KEMS, the fosterite content remained the same within experimental uncertainties (95 \pm 5 wt. $\%$ - before, $96 \pm 5$ wt. $\%$ - after) and the fayalite content diminished 1.0 \pm 0.3 wt. $\%$. This wt. $\%$ decrease of the fayalite content translates to a decrease of $0.7 \pm 0.2 \mathrm{wt}$. $\%$ of $\mathrm{Fe}$ and $1.1 \pm 0.4$ wt. \% of $\mathrm{FeO}$. We use $\mathrm{Fo}_{95} \mathrm{Fa}_{5}$ throughout the manuscript since this was the measured composition before KEMS and it has only decreased $1.0 \pm 0.3$ wt. \% of its fayalite content. Above the melting point or solidus, the fayalite content diminished to $0.21 \pm 0.01 \mathrm{wt}$. \% ( $0.16 \pm 0.01$ wt. $\%$ of Fe or $0.18 \pm 0.01$ wt. \% of FeO). Considering the composition of the sample before KEMS, olivine almost lost all of its iron content ( $4.7 \pm 0.2 \mathrm{wt}$. \% of fayalite, $3.4 \pm$ 0.2 wt. $\%$ of Fe and $4.9 \pm 0.4$ wt. \% of FeO. 


\subsection{Vapor Composition}

The ionic species detected by KEMS in the vapor phase of the olivine sample between 1751 $2225 \mathrm{~K}$ are listed in Table 2. Appearance potentials were measured via extrapolation of the linear segment of the ionization efficiency curves and these are statistically indistinguishable to those reported earlier (Levin, Lias et al. 1982). The neutral precursors of these ions were identified from their mass-to-charge ratio and their appearance potentials. The primary vapor species above olivine are thus $\mathrm{Fe}(\mathrm{g}), \mathrm{Mg}(\mathrm{g}), \mathrm{SiO}(\mathrm{g}), \mathrm{O}_{2}(\mathrm{~g})$, and $\mathrm{O}(\mathrm{g})$. No major breaks were observed in the ionization curves, indicating that fragmentation of the polyatomic species did not occur during the ionization process. As discussed previously, $\mathrm{O}_{2}(\mathrm{~g})$ does fragment to $\mathrm{O}(\mathrm{g})$ at higher ionizing electron energies and low electron energies were used to prevent this.

\subsection{Time to Equilibration}

KEMS equilibrium studies were conducted after isothermal heating (Fig. 3) when the ion intensities of the vapor species of olivine were constant with time. The ion intensities of iron and silicon oxide increased from $20 \times 10^{3}$ cps to approximately $30 \times 10^{3}$ cps and from $5 \times 10^{3}$ cps to approximately $10 \times 10^{3} \mathrm{cps}$ in the initial $5 \mathrm{~h}$ of the isothermal experiment, respectively. Although the ion intensities of iron and silicon monoxide changed drastiscally in the initial stage of vaporization, the ion intensities of magnesium, and molecular and atomic oxygen were apparently constant with time during the whole isothermal experiment. This is see in the data points on the isothermal graph in Fig. 3, where the values of the ion intensies of these species changed slightly over time. Such small fluctuations of the ion intesities of the vapor species are not expected to influence the thermodynamic data above the experimental uncertainties.

The attainment of equilibrium in a Knudsen cell is a critical issue in Knudsen effusion studies (Cater 1979). Dohmen et al. (1998) have carefully examined the system Fe/olivine and used a Knudsen cell to monitor reaction progress. They discuss preferential loss of $\mathrm{Mg}(\mathrm{g})$ from the olivine and compositional zoning within the grains. Although their system is compositionally different from ours, such processes must be considered in our system as well. We believe that equilibrium in our cell is reached due to (1) Our cell was kept at $1890 \mathrm{~K}$ for $>10 \mathrm{~h}$ (2) The vapor pressures were constant within experimental error as discussed above (3) A plot of the logarithm 
of vapor vs inverse temperature was linear.

\subsection{Thermodynamic Properties}

\subsubsection{Reference Materials}

The data for vapor pressures of the species above the three reference materials $-\mathrm{SiO}_{2}, \mathrm{FeO}$ and $\mathrm{MgO}$ - are shown in Fig. 4. We used 'FeO' with excess Fe to fix the composition of ' $\mathrm{FeO}$ '. As noted, the $\mathrm{P}\left(\mathrm{O}_{2}\right)$ in this case is below the limits of detectability and the $\mathrm{P}\left(\mathrm{O}_{2}\right)$ used in reaction (2) was calculated from the measured $\mathrm{P}(\mathrm{Fe})$ and the data in FactSage (Bale, Chartrand et al. 2002). These in turn were used to calculate their equilibrium constants for reactions (3-5), which are also shown in Fig. 4. For $\mathrm{MgO}$ and $\mathrm{SiO}_{2}$ the data taken here were reasonably close to published equilibrium data from the tables. (Chekhovskoi, Ivanisov et al. 1993, Bale, Chartrand et al.2002) Data were used only where (1) the ratio of the partial pressures of the metal-bearing and diatomic oxygen were close to that predicted from equilibrium calculations and (2) the calculated equibrium between diatomic and monatomic oxygen was close to that predicted. Differences are due to uncertainty in the ionization cross sections (Eqn. (2)) and small deviations from equilibrium encountered in a Knudsen cell. This underscores the need for running reference materials under the same experimental conditions as the solid solution under examination.

\subsubsection{Olivine}

Initial measurements were taken through the melting point (solidus) into the two phase region, and above the liquidus as shown in Fig. 5. Near the solidus there were significant discontinuities in the measured ion intensities. These suggest the onset of melting is near $2050 \mathrm{~K}$ for $\mathrm{Fo}_{95} \mathrm{Fa}_{5}$, which is consistent with the phase diagram for forsterite-fayalite, as shown in Fig. 1(a) (Bowen and Schairer 1935). Our chemical analysis indicates that after melting there is a rapid loss of Fe, which is also consistent with these changes in partial pressures on melting. Mysen \& Kushiro (1988) studied forsterite vaporization using Knudsen effusion weight loss measurements. They also noticed a large discontinuity at $\sim 1700{ }^{\circ} \mathrm{C}(\sim 1973 \mathrm{~K})$ where liquid formed in their experiments, about 190 degrees below the forsterite melting point of $1890{ }^{\circ} \mathrm{C}$ $(2163 \mathrm{~K})$. The large melting point depression may be due to impurities in their sample (e.g., see pp. 1953-1954 of Nagahara et al. 1994). Mysen \& Kushiro's (1988) data were much more scattered above than below the melting point, as seen in their Table 2. Vapor pressure 
measurements below the melting point are shown in Fig. 6. Using the procedure of equilibrium constant ratios, as discussed previously, thermodynamic activities are derived as a function of inverse temperature and shown in Fig. 7. Partial molar enthalpies are determined from the slope of this plot and listed in Table 3 .

\section{Discussion}

\subsection{Enthalpy and Entropy of Vaporization for Olivine}

Treating the system as a Fo-Fa pseudo-binary, we computed partial molar enthalpies of vaporization of fayalite and forsterite from the measured $\mathrm{Fe}$ and $\mathrm{Mg}$ partial vapor pressures over the $\mathrm{Fo}_{95} \mathrm{Fa}_{0.05}$ sample. Our treatment follows that of Nagahara et al. (1994) and Dohmen et al. (1998). At chemical equilibrium between olivine and vapor the chemical potentials of forsterite $\left(\mu_{\mathrm{Fo}}\right)$ and fayalite $\left(\mu_{\mathrm{Fa}}\right)$ are equal in the two coexisting phases. This is expressed by the equations:

$$
\begin{aligned}
& F a(\text { olivine })=F a(\text { gas }) \\
& \mu_{F a}(\text { olivine })=\mu_{F a} \text { (gas) } \\
& F o(\text { olivine })=F o(\text { gas }) \\
& \mu_{F o}(\text { olivine })=\mu_{F o} \text { (gas) }
\end{aligned}
$$

The reaction isotherms for the two vaporization reactions are

$$
\begin{aligned}
& \mu_{F a}(\text { gas })-\mu_{F a}(\text { olivine })=0=\left[\mu_{F a(\text { gas })}^{o}-\mu_{F a(\text { olivine })}^{o}\right]+R T \ln K_{F a} \\
& \mu_{F o}(\text { gas })-\mu_{F o}(\text { olivine })=0=\left[\mu_{F o(\text { gas })}^{o}-\mu_{F o(\text { olivine })}^{o}\right]+R T \ln K_{F o}
\end{aligned}
$$

The equilibrium constants $\mathrm{K}_{\mathrm{i}}$ (where $\mathrm{i}=\mathrm{Fa}$ or $\mathrm{Fo}$ ) are given by

$$
\begin{aligned}
& K_{F a}=\exp \left(-\left[\mu_{F a(\text { gas })}^{o}-\mu_{F a(\text { olivine })}^{o}\right] / R T\right)=\frac{f_{F a}}{a_{F a}} \sim \frac{P_{F a}}{X_{F a}}=\frac{P_{F e}}{X_{F a}} \\
& K_{F o}=\exp \left(-\left[\mu_{F o(\text { gas })}^{o}-\mu_{F o \text { (olivine) })}^{o}\right] / R T\right)=\frac{f_{F o}}{a_{F o}} \sim \frac{P_{F o}}{X_{F o}}=\frac{P_{M g}}{X_{F o}}
\end{aligned}
$$


The equilibrium constant expressions above assume ideality for olivine and gas (i.e., fugacity $f$ $=$ partial pressure $\mathrm{P}$ and thermodynamic activity $\mathrm{a}=$ mole fraction $\mathrm{X}$ ). An ideal gas is a good assumption at the high temperatures and low total pressures in the KEMS experiments.

We initially assume ideal solid solution of fayalite and forsterite in olivine and then explore the effects of non-ideality, which are small (e.g., Dachs \& Geiger 2007, von Seckendorff \& O’Neill 1993, Wiser \& Wood 1991, Nafziger \& Muan 1967). To first approximation, the temperature dependence of the $\mathrm{K}$ values for the vaporization reactions are given by

$$
\begin{aligned}
& \ln K_{F a}=\ln \left(\frac{P(F e)}{X(F a)}\right)=\frac{\Delta S_{v a p}^{F a}}{R}-\frac{\Delta H_{v a p}^{F a}}{R T} \\
& \ln K_{F o}=\ln \left(\frac{P(M g)}{X(F o)}\right)=\frac{\Delta S_{v a p}^{F o}}{R}-\frac{\Delta H_{v a p}^{F o}}{R T}
\end{aligned}
$$

The $\Delta \mathrm{H}_{\text {vap }}$ and $\Delta \mathrm{S}_{\text {vap }}$ values for forsterite and fayalite calculated assuming ideal solid solution in olivine are given in Table 4. Here $\mathrm{R}$ and $\mathrm{T}$ are the gas constant and absolute temperature, respectively. There is fairly good agreement with the prior work of Nagahara et al. (1994) on pure forsterite and Piacente et al. (1975) on a Fo-rich olivine ( $\left.\mathrm{Fo}_{90} \mathrm{Fa}_{10}\right)$ similar in composition to our sample. However Mysen \& Kushiro (1988) derived a much higher $\Delta \mathrm{H}_{\mathrm{vap}}$ for their forsterite sample. As mentioned earlier their sample also melted $190 \mathrm{~K}$ below the accepted value (2163 K) for forsterite and may have contained impurities, causing a melting point depressions. Our fayalite (liquid) $\Delta \mathrm{H}_{\text {vap }}$ and $\Delta \mathrm{S}_{\text {vap }}$ values also show good agreement with those of Nagahara et al. (1994) and Piacente et al. (1975). The vapor pressures $\left(\mathrm{P}_{\mathrm{vap}}\right)$ of pure forsterite and pure fayalite were calculated at their triple points (2163 K and $1490 \mathrm{~K}$, respectively) from our measured $\mathrm{Mg}$ and $\mathrm{Fe}$ partial pressures over $\mathrm{Fo}_{95} \mathrm{Fa}_{5}$ olivine assuming ideal solid solution:

$$
\begin{aligned}
& \ln \left(\frac{P(M g)}{X(F o)}\right)=21.992-\frac{70,364 \pm 418}{T} \\
& \ln \left(\frac{P(F e)}{X(F a)}\right)=18.769-\frac{51,452 \pm 306}{T}
\end{aligned}
$$

The calculations give $\mathrm{P}_{\mathrm{vap}}=2.6 \times 10^{-5}$ bar at the forsterite triple point versus $5.2 \times 10^{-5} \mathrm{bar}$ determined by Nagahara et al. (1994) and $\mathrm{P}_{\mathrm{vap}}=14 \times 10^{-8}$ bar at the fayalite triple point versus $6.3 \times 10^{-8}$ bar from Nagahara et al. (1994). Agreement is slightly better for forsterite than fayalite but is within a factor of 2.2 in both cases. Fig. 8 is a plot of $\ln (P(F e) / P(M g))$ versus inverse 
temperature. The close agreement between the observed and calculated values shows the near ideality of olivine as a pseudo-binary system.

As mentioned in the Introduction, the forsterite - fayalite solid solution has small positive deviations from ideality. There is no statistically significant excess entropy of mixing (Dachs \& Geiger 2007), so a symmetric regular solution model with one parameter, as recommended by many groups (e.g., Dachs \& Geiger 2007, von Seckendorff \& O’Neill 1993, Wiser \& Wood 1991, Kitayama \& Katsura 1968, Larimer 1968, Nafziger \& Muan 1967) is sufficient for describing the small amounts of non-ideality. The $\mathrm{Mg}^{2+}$ and $\mathrm{Fe}^{2+}$ cations can be distributed on the M1 and M2 octahedral sites in olivine (Muan 1967, Nafziger \& Muan 1967) so the equations for the activity coefficients of forsterite and fayalite are written in terms of one half formula unit, e.g. $\mathrm{MgSi}_{0.5} \mathrm{O}_{2}\left(=1 / 2 \mathrm{Mg}_{2} \mathrm{SiO}_{4}\right)$ and $\mathrm{FeSi}_{0.5} \mathrm{O}_{2}\left(=1 / 2 \mathrm{Fe}_{2} \mathrm{SiO}_{4}\right)$. We used the equations

$$
\begin{aligned}
& R T \ln \left(\gamma_{\mathrm{FeSi}_{.5} \mathrm{O}_{2}}\right)=R \operatorname{Rln}\left(\gamma_{\mathrm{Fa}}\right)=W_{G} X_{M g S i_{.5} \mathrm{O}_{2}}^{2} \\
& R T \ln \left(\gamma_{\mathrm{MgSi}_{.5} \mathrm{O}_{2}}\right)=R \operatorname{Rln}\left(\gamma_{\mathrm{Fo}}\right)=W_{G} X_{\mathrm{FeSi} i_{5} \mathrm{O}_{2}}^{2}
\end{aligned}
$$

Here $\gamma_{i}$ is the activity coefficient of component $i$. We use a Margules parameter $\mathrm{W}_{\mathrm{G}}=3,700 \mathrm{~J}$ mol $^{-1}$ (von Seckendorff \& O'Neill 1993, Wiser \& Wood 1991). For the $\mathrm{Fo}_{95} \mathrm{Fa}_{5}$ olivine over the $1750-2050 \mathrm{~K}$ range, this regular solution model gives

$$
\begin{gathered}
\ln \left(\gamma_{F a}\right)=\frac{402}{T} ; \gamma_{F a}=1.26 \text { to } 1.22 \\
\ln \left(\gamma_{F o}\right)=\frac{1}{T} ; \gamma_{F o}=1
\end{gathered}
$$

In other words the $\mathrm{Fo}_{95} \mathrm{Fa}_{5}$ olivine is ideal within $26 \%$, and Table 4 shows the $\Delta \mathrm{H}_{\text {vap }}$ and $\Delta \mathrm{S}_{\text {vap }}$ values for the regular solution model are very similar to those assuming ideal solid solution.

Table 1 shows the composition of the olivine changed by about 1 mol\% over the course of the KEMS experiments from $\mathrm{Fo}_{95} \mathrm{Fa}_{5}$ to $\mathrm{Fo}_{96} \mathrm{Fa}_{4}$, and it is possible this change could have affected the $\Delta \mathrm{H}_{\text {vap }}$ and $\Delta \mathrm{S}_{\text {vap }}$ values computed from our work. But the effect if any seems minor because 
of the good agreement of our calculated vapor pressures at the fayalite and forsterite triple points with those reported by Nagahara et al. (1994) and with their $\Delta \mathrm{H}_{\mathrm{vap}}$ and $\Delta \mathrm{S}_{\mathrm{vap}}$ values.

\subsection{Fractional vaporization of Fe and Mg from Olivine}

In their pioneering study, Nagahara et al. (1988) showed fractional vaporization of olivine in their Knudsen effusion weight loss experiments from electron microprobe analyses of the vaporized residual olivine. But they did not measure the partial pressures of the evaporating gas species. Ozawa \& Nagahara (2000) studied the kinetics of fractional vaporization of $\mathrm{FO}_{92} \mathrm{Fa}_{8}$ olivine at $1414{ }^{\circ} \mathrm{C}(1687 \mathrm{~K})$ but did not measure gas chemistry or study the temperature dependence. Fig. 8 shows that the measured Fe/Mg partial pressure ratio in the saturated vapor in equilibrium with olivine is larger than the Fa/Fo molar ratio in olivine,

$$
\frac{(\mathrm{Fe} / \mathrm{Mg})_{\text {gas }}}{(\mathrm{Fe} / \mathrm{Mg})_{\text {olv }}}>1
$$

The fractional vaporization of $\mathrm{Fe}$ and $\mathrm{Mg}$ is a consequence of the different Gibbs energies of vaporization of the fayalite and forsterite components in solid solution in olivine. We can show this by rearranging the equations for $\mathrm{K}_{\mathrm{Fa}}$ and $\mathrm{K}_{\mathrm{Fo}}$ to solve for the $\mathrm{Fe} / \mathrm{Mg}$ ratio in the gas:

$$
\ln \left(\frac{F e}{M g}\right)_{g a s}=\ln \left(\frac{a_{F a}}{a_{F o}}\right)_{O l v}-\ln \left(\frac{-\Delta G_{v a p}^{o}(F o) / R T}{-\Delta G_{v a p}^{o}(F a) / R T}\right)
$$

The $\Delta G_{v a p}^{o}$ values for forsterite and fayalite are given by

$$
\Delta G_{v a p}^{o}=\Delta H_{v a p}^{o}-T \Delta S_{v a p}^{o}
$$

The values for the enthalpy and entropy of vaporization are in Table 4. Agreement between our data and the literature data is good for fayalite. For forsterite, there is about $7 \%$ difference between our data and that of Piacente et al. (1975) and Nagahara et al. (1994) and about 9.4\% difference between our data and that of Mysen and Kushiro (1988). Nagahara et al. (1994) points out out that the larger values obtained by Mysen and Kushiro (1988) are possibly due to their weight loss measurement including the capsule, cap, and wire in addition to the sample, which could overestimate the weight loss. Differences could also be attributed to possible cell reactions - as discussed in the Supplementary Material, only Ir showed some degree of inertness to olivine. 
We reach exactly the same conclusion if we treat olivine vaporization as an exchange reaction as done by Dohmen et al. (1998). In this case

$$
\mathrm{MgSi}_{.5} \mathrm{O}_{2}(\mathrm{Fo})+\mathrm{Fe}(\mathrm{g})=\mathrm{FeSi}_{.5} \mathrm{O}_{2}(\mathrm{Fa})+\mathrm{Mg}(g)
$$

At chemical equilibrium,

$$
\mu_{M g(g)}+\mu_{F a}=\mu_{F e(g)}+\mu_{F o}
$$

The reaction isotherm for the exchange reaction is

$$
\mu_{M g(g)}+\mu_{F a}-\left[\mu_{F e(g)}+\mu_{F o}\right]=0=\left[\mu_{M g(g)}^{o}+\mu_{F a}^{o}-\mu_{F e(g)}^{o}-\mu_{F o}^{o}\right]+R T \ln K_{e x}
$$

The equilibrium constant $\left(\mathrm{K}_{\mathrm{ex}}\right)$ for the exchange reaction is

$$
K_{e x}=\exp \left(-\left[\mu_{M g(g)}^{o}+\mu_{F a}^{o}-\mu_{F e(g)}^{o}-\mu_{F o}^{o}\right] / R T\right)=\frac{f_{M g} a_{F a}}{f_{F e} a_{F o}} \sim \frac{P_{M g} X_{F a}}{P_{F e} X_{F o}}
$$

The relationship between $\mathrm{Fa}$ and Fo in olivine and $\mathrm{Fe}$ and $\mathrm{Mg}$ in the gas is thus

$\frac{a_{F a}}{a_{F o}}=K_{e x} \cdot \frac{f_{F e}}{f_{M g}} \sim \frac{X_{F a}}{X_{F o}}=K_{e x} \cdot \frac{P_{F e}}{P_{M g}}$

The right most part of this equation is the approximate expression derived by Dohmen et al. (1998) and shows the equality of our two treatments.

In principle we could use the Fe/Mg ratio in the gas to compute the ratio of $\Delta G_{v a p}^{o}$ values and if the value for one endmember were known accurately, then the other could be computed from the KEMS data for the olivine. This method can be used to compute $\Delta G_{v a p}^{o}$ for minor components dissolved in olivine such as $\mathrm{CaSi}_{0.5} \mathrm{O}_{2}, \mathrm{NiSi}_{0.5} \mathrm{O}_{2}, \mathrm{MnSi}_{0.5} \mathrm{O}_{2}$, and $\mathrm{CoSi}_{0.5} \mathrm{O}_{2}$ but it has not been done to our knowledge.

Other binary solid solutions with cigar-shaped phase diagrams should fractionate the more and less volatile end members during vaporization. For example, the solid solutions of fayalite tephroite $\left(\mathrm{Mn}_{2} \mathrm{SiO}_{4}\right)$, forsterite - tephroite, $\mathrm{Ni}_{2} \mathrm{SiO}_{4}$ - forsterite, $\mathrm{Co}_{2} \mathrm{SiO}_{4}$ - forsterite, and so on, should have this behavior. The albite $\left(\mathrm{NaAlSi}_{3} \mathrm{O}_{8}\right)$ - anorthite $\left(\mathrm{CaAl}_{2} \mathrm{Si}_{2} \mathrm{O}_{8}\right)$ phase diagram for plagioclase feldspar (Bowen 1913) is probably the most well-known cigar-shaped phase diagram in mineralogy and it shows fractional vaporization of $\mathrm{Ca}$ and $\mathrm{Na}$ (Nagahara \& Kushiro 1989, Nagahara 1990, Nagahara et al. 1993). The Ca-rich vaporization residues and Na-rich vapor condensates show complementary compositions (e.g., Figure 7 of Nagahara \& Kushiro 1989). 
They did also Knudsen effusion weight loss measurements and the partial pressures of the different evaporating gases were not measured.

\subsection{Olivine as a Pseudo-Ternary and Comparison to Assessments}

As discussed, olivine can also be regarded a pseudo-ternary of $\mathrm{MgO}-{ }^{-} \mathrm{FeO}^{\prime}-\mathrm{SiO}_{2}$. This is particularly important as the reported vapor pressures originate from each of these three components. These vapor pressures lead to thermodynamic activities of these components. Our data can then be compared to recent thermodynamic assessments of the $\mathrm{MgO}-{ }^{-} \mathrm{FeO}^{-}-\mathrm{SiO}_{2}$ system by Fabrichnaya and colleagues (Fabrichnaya 1998, Andersson, Helander et al. 2002), to support the consistency of both our measurements and their thermodynamic assessment. Their database was constructed with all available thermodynamic and phase data at the time of the assessment and provides a self-consistent thermodynamic description of this system. A comparison of the data from this study to this assessment should indicate if our data is consistent with previous measurements and also allows inferences about the exact phase composition of the olivine. It also should suggest improvements for future assessments and experiments.

Ideally activity measurements and calculations should be conducted in the two phase regions of the pseudo-ternary (Fig. 1), i.e. olivine + protopyroxene, olivine + liquid or olivine + magnesiowüstite. The olivine line in Fig. 1(b) necessarily has an activity gradient across it. Figs. 9(a) and (b) are calculations of component activities in these regions using ThermoCalc (Andersson, 2002). Fig. 9(a) for the olivine + proto-pyroxene and olivine + liquid region was calculated with the olivine composition used here and a little excess silica. The compositional input was thus $x(\mathrm{MgO})=0.33, \mathrm{x}(\mathrm{FeO})=0.03, \mathrm{x}(\mathrm{Fe})=1 \times 10^{-5}$, and $\mathrm{x}\left(\mathrm{SiO}_{2}\right)=0.34$. Fig. 9(b) for the olivine + magnesiowüstite was calculated with the olivine composition used here and a little excess $\mathrm{MgO}$. In this case the compositional input was $\mathrm{x}(\mathrm{MgO})=0.63, \mathrm{x}(\mathrm{FeO})=0.03, \mathrm{x}(\mathrm{Fe})=1$ $\mathrm{x} 10^{-5}$, and $\mathrm{x}\left(\mathrm{SiO}_{2}\right)=0.34$. It should be noted that in these two phase regions in a three component system, activity would vary with composition. Since we do not know the composition with extreme precision, these input compositions approximate the analyzed compositions. Thus the calculated values of activities and partial molar enthalpies would not be expected to be identical to our measurements. However, they should follow the same trends as our measurements, which was indeed observed. 
As discussed, the material in our Knudsen cell was shown via XRD to be pure olivine. However the data in Fig. 7 are close to the calculations in Fig. 9(a) for the excess silica olivine, which equilibrates to olivine + liquid. Our measurements indicate a high silica activity. The equilibrium calculations indicate a small amount of liquid (x(liquid) 0.04). This may be amorphous on cooling and/or be too small an amount to detect from XRD.

Table 3 compares the measured partial molar enthalpies of each component to those calculated from the database discussed above. Although the measurements and the model show the same trends, agreement between our measurements and the database of Fabrichnaya (Fabrichnaya 1998 ) is only approximate for the partial molar enthalpy of $\mathrm{SiO}_{2}$ and $\mathrm{FeO}$ and there is some disagreement for the partial molar enthalpy of $\mathrm{MgO}$. Some of this can be attributed to compositional differences, as is discussed. However further studies are necessary in welldefined two phase regions to resolve these discrepancies.

\subsection{Olivine Vapor Pressure Equation}

The total vapor pressure $\left(\mathrm{P}_{\mathrm{T}}\right)$ above olivine of composition $\mathrm{Fo}_{95} \mathrm{Fa}_{5}$ was calculated by modifying the tabulated vapor pressures for $\mathrm{MgO}, \mathrm{Fe}$-rich $\mathrm{FeO}$, and $\mathrm{SiO}_{2}$ by their measured activities in Fig. 7. The tabulated vapor pressures were taken from the FactSage code and databases (Bale, 2002). The derived vapor pressure equation is

$$
\log P_{T}(\text { bar })=6.9908( \pm 0.0605)-\frac{22,519( \pm 110)}{T}
$$

This equation gives a total vapor pressure of $\sim 7 \times 10^{-6}$ bars at $1850 \mathrm{~K}$ (see Fig. 10).

For comparison, the total vapor pressure for the $\mathrm{Fo}_{90} \mathrm{Fa}_{10}$ olivine studied by Piacente et al. (1975) is $\sim 1 \times 10^{-4}$ bars at the same temperature, over 10 times larger. This could be due to the higher fayalite content of their olivine (unlikely) or it could be due to issues such as the choice of cross sections in the conversion of ion intensity to vapor pressures (eqn. (2)). Their observations are similar to ours otherwise - they obtain the same relative volatility sequence $\mathrm{Fe}>\mathrm{SiO}>\mathrm{O}_{2}>\mathrm{Mg}$ and their data give similar $\Delta \mathrm{H}_{\text {vap }}$ and $\Delta \mathrm{S}_{\text {vap }}$ values for forsterite and fayalite, as discussed above. But their vapor pressure is about 10 times larger over the temperature range studied (see Fig. 10) and the cause is unknown. 


\subsection{FeO Gas}

Another similarity between our results and those of Piacente et al. (1975) is the absence of FeO (g). Thermodynamic calculations using JANAF data predict $\mathrm{FeO} / \mathrm{Fe}$ ratios $\sim 0.1$ in the saturated vapor over olivine which is not observed. Clearly there is a discrepancy between our observations and those of Piacente et al. (1975) as compared to the dissociation energy of $\sim 414$ $\mathrm{kJ} \mathrm{mol}^{-1}$ (based on spectroscopic measurements) adopted by JANAF in 1966. Since 1966, there are several more recent measurements of the $\mathrm{FeO}$ dissociation energy that give lower values, e.g., $389 \pm 13 \mathrm{~kJ} \mathrm{~mol}^{-1}$ (Murad 1980), $401 \pm 8 \mathrm{~kJ} \mathrm{~mol}^{-1}$ (Smoes \& Drowart 1984), $403 \pm 1 \mathrm{~kJ}$ $\mathrm{mol}^{-1}$ (Chestakov et al. 2005), $405 \pm 13 \mathrm{~kJ} \mathrm{~mol}^{-1}$ (Hildenbrand 1975), and $406 \pm 13 \mathrm{~kJ} \mathrm{~mol}^{-1}$ (Balducci et al. 1971). More work is necessary to resolve this discrepancy.

\subsection{Molten Olivine Vaporization}

Fig. 1(a) shows the phase diagram for the forsterite $\left(\mathrm{Mg}_{2} \mathrm{SiO}_{4}\right)$ - fayalite $\left(\mathrm{Fe}_{2} \mathrm{SiO}_{4}\right)$ binary determined by Bowen \& Schairer (1935). In this diagram, the hollow circles are the points measured by Bowen \& Schairer (1935), Bowen \& Anderson (1914) for forsterite, and Bowen \& Schairer (1932) for fayalite. The vertical dashed line shows the composition of our olivine sample $\mathrm{Fo}_{95} \mathrm{Fa}_{5}$ and the red dots are the expected solidus $\left(1825^{\circ} \mathrm{C}\right)$ and liquidus temperatures $\left(1875^{\circ} \mathrm{C}\right)$ from the phase diagram. As mentioned earlier, we observed melting at $\sim 2050 \mathrm{~K}(\sim$ $1777^{\circ} \mathrm{C}$ ). The experimental uncertainties given in Table II of (Bowen \& Schairer 1935) are \pm 3 ${ }^{\circ} \mathrm{C}$ at the fayalite melting point rising to $\pm 20{ }^{\circ} \mathrm{C}$ at the forsterite melting point. They also stated the accuracy of their solidus measurements (in terms of olivine composition) was up to $3-4 \%$ in the percentages of forsterite and fayalite. In contrast, their liquidus measurements have insignificant errors in the olivine composition. Thus we believe our measured solidus is consistent with the pseudo-binary phase diagram.

The phase diagram in Figure 1(a) shows $\mathrm{Fo}_{95} \mathrm{Fa}_{5}$ olivine is in equilibrium with melt of composition $\mathrm{Fo}_{79.5} \mathrm{Fa}_{20.5}$ at the solidus (the horizontal dashed line and points). At the solidus, an infinitesimal amount of melt forms and if equilibrium between olivine crystals + melt is maintained during heating in the Knudsen cell, the fayalite content in the melt should move toward the upper left on Fig. 1(a). For example, at $1850^{\circ} \mathrm{C}$ olivine and melt in equilibrium with 
each other (the small blue dots in Fig. 1(a)) have compositions of $\mathrm{FO}_{97} \mathrm{Fa}_{3}$ and $\mathrm{Fo}_{87} \mathrm{Fa}_{13}$, and the system is $\sim 80 \%$ olivine and $20 \%$ melt. At the liquidus (upper red dot at $1875^{\circ} \mathrm{C}$ ) the compositions of olivine and melt have converged and the system is $\sim 100 \%$ melt with an infinitesimal amount of solid and the same bulk composition $\mathrm{Fo}_{95} \mathrm{Fa}_{5}$.

However, our data taken above the solidus did not show this phenomenon. Instead it seems the crystals + melt did not equilibrate because significantly more $\mathrm{Fe}$ (than $\mathrm{Mg}$ ) was vaporized from the two phase olivine + melt system in the Knudsen cell and almost pure forsterite was left at the end. It is uncertain if the solid + melt equilibrated on the short time scale of our experiments because Bowen \& Schairer (1935) stated it was impossible to prepare unzoned (ie., homogeneous) olivines for their solidus temperature measurements.

Incongruent melting of $\mathrm{FeO}$-bearing olivine may account for our observations. Liquid $\mathrm{Fe}_{2} \mathrm{SiO}_{4}$ decomposes to produce $\mathrm{Fe}, \mathrm{Fe}_{2} \mathrm{O}_{3}$, and $\mathrm{SiO}_{2}$ (Stebbins \& Carmichael 1984)

$$
0.9620 \mathrm{Fe}_{2} \mathrm{SiO}_{4} \text { (melt) }+0.0253 \mathrm{Fe}_{2} \mathrm{O}_{3} \text { (melt) }+0.0253 \mathrm{Fe} \text { (liq) }+0.0280 \mathrm{SiO}_{2} \text { (melt) }
$$

The Fe vapor pressure over Fe (liq) is larger than that over molten olivine, e.g., at $2050 \mathrm{~K}$ the values are $10^{-3.16}$ bar (liquid $\mathrm{Fe}$ ) vs. $10^{-4.05}$ bar ( $\mathrm{FO}_{95} \mathrm{Fa}_{5}$ olivine). According to LeChatelier's Principle, $\mathrm{Fe}$ loss due to vaporization causes more $\mathrm{Fe}_{2} \mathrm{SiO}_{4}$ (liq) to decompose giving more liquid $\mathrm{Fe}, \mathrm{Fe}_{2} \mathrm{O}_{3}$, and $\mathrm{SiO}_{2}$. The $\mathrm{Fe}_{2} \mathrm{O}_{3}$ also vaporizes and is lost. Eventually none or almost none of the $\mathrm{Fe}$ is left and the remaining silica + forsterite react to form enstatite via

$$
\mathrm{SiO}_{2}(\text { silica })+2 \mathrm{Mg}_{2} \mathrm{SiO}_{4}(\text { forsterite })=2 \mathrm{MgSiO}_{3}(\text { protoenstatite })
$$

If equilibrium is reached, this reaction proceeds until all silica is consumed; for our sample XRD shows the final molar ratio of forsterite to protoenstatite is 4 to 1 , but a few percent of $\mathrm{SiO}_{2}$, which is below the XRD detection limit, may still be present, as discussed earlier.

\subsection{Implications for Silicate Atmospheres of Hot Rocky Exoplanets (HRE)}

Table 5 lists several hot rocky exoplanets (HRE), which have surface temperatures greater than $1000 \mathrm{~K}$ at the sub-stellar point (assuming unit albedo, Kite et al. 2016). They are rocky based on their mass and radius (e.g., Fig 4 of Dressing et al. 2015). The HRE are thought to have silicate 
vapor atmospheres (e.g., see Kite et al. 2016; Ito et al. 2015; Schaefer \& Fegley 2009) and our work gives constraints on the $\mathrm{Fe} / \mathrm{Mg}$ atomic ratio in these atmospheres.

We discussed fractional vaporization of $\mathrm{Fe}$ and $\mathrm{Mg}$ from olivine in section 4.2. The equation describing this is plotted in Figure 8 and is

$\ln \left(\frac{\mathrm{Fe}}{\mathrm{Mg}}\right)_{\text {gas }}=\frac{18,912( \pm 112)}{T}-6.167( \pm 0.036)$

We used this equation to compute the $(\mathrm{Fe} / \mathrm{Mg})$ values listed in Table 5 and plotted in Figure 11. The surface temperatures at the sub-stellar point for each HRE were taken from Table 3 of Kite et al. (2016). Pahlevan et al. (2011) give the low and high end of the temperature range (2500 $3500 \mathrm{~K}$ ) for the silicate vapor atmosphere on the Earth after the Moon-forming impact. Our results predict the $(\mathrm{Fe} / \mathrm{Mg})_{\text {gas }}$ values will decrease with increasing surface temperature as more $\mathrm{Mg}$ is vaporized from the magma oceans on these planets.

Prior theoretical studies predicted qualitatively similar behavior (e.g., Fig 2 of Schaefer \& Fegley 2009, Fig 4 of Fegley \& Schaefer 2014, Fig 2 of Ito et al. 2015). For example, Fig 2A of Ito et al. (2015) gives $\mathrm{Fe} / \mathrm{Mg}$ ratios of 4.5, 2.7, and 1.3 at 2000, 2500, and $3000 \mathrm{~K}$, respectively. Figure 4 of Fegley \& Schaefer (2014) gives Fe/Mg ratios of 2.9, 1.1, and 0.6, respectively, at the same temperatures. Ito et al. (2015) used a regular solution model (MELTS) while Fegley \& Schaefer (2014) and Schaefer \& Fegley (2009) used an associated species model (MAGMA). Our results agree with both models (better with Ito et al. 2015), but are preferable because they are based on experimental vaporization data. In principle it should be possible to measure vaporization of minor and trace elements that substitute for $\mathrm{Mg}$ and $\mathrm{Fe}$ in olivine (e.g., $\mathrm{Ni}, \mathrm{Ca}$, $\mathrm{Mn}, \mathrm{Co}$ ) and predict their abundances in silicate vapor atmospheres but this is a topic for future study.

\section{Summary and Conclusions}

The vaporization of olivine of composition $\mathrm{Fo}_{95} \mathrm{Fa}_{5}$ has been studied from $1750-2250 \mathrm{~K}$. It was found that impurities in the mineral could be removed by heating in a vacuum at $1853 \mathrm{~K}$ for $10 \mathrm{~h}$. The vaporization behavior was studied with Knudsen Effusion Mass Spectrometry to obtain partial pressures as a function of inverse temperature. An iridium cell was fairly inert to olivine below the melting point; however there was some reaction above the melting point. The 
onset of melting was observed at $\sim 2050 \mathrm{~K}$, consistent with the literature. It was also observed that significant losses of the $\mathrm{FeO}$ component occurred at the melting point.

Thermodynamic data was taken on this composition below the melting point. The equilibrium constant for each component $\left(\mathrm{MgO}, \mathrm{Fe} / \mathrm{FeO}\right.$, and $\left.\mathrm{SiO}_{2}\right)$ were compared to the equilibrium constant for the pure material. Thermodynamic activities and partial molar enthalpies were derived for these components in olivine. By treating the system as a Fo-Fa pseudo-binary, we derived the enthalpy and entropy of vaporization. Our data compared favorably to that of other investigators. Our data also showed that olivine fractionates with the $\mathrm{FeO}$ component vaporizing preferentially. By treating the system as a $\mathrm{MgO}-{ }^{'} \mathrm{FeO}$ '- $-\mathrm{SiO}_{2}$ psuedo-ternary, we compare data to activities calculated from an assessed thermodynamic databases in the literature. We also used our data to derive total vapor pressures and concluded with some comments on possible silicate vapors in the atmosphere of the hot, rocky exoplanets.

\section{Acknowledgments}

We are grateful to Dr. Olga Fabrichnaya (TU-Freiburg, Germany) for sharing her database and assistance with the calculations and R. Rogers (NASA Glenn) for assistance with X-ray diffraction.

This work was supported by NASA EPSCoR (Experimental Program to Stimulate Competitive Research). NNX13AE52A, "Understanding the Atmospheres of Hot Earths and the Impact on Solar System Formation" with NASA Glenn Research Center, Missouri State University and Washington University, St. Louis. GCCC is grateful to the ORAU/NASA Post-Doctoral Fellowship program for support. NSF Astronomy Program Grant AST-1412175 also supported work by $\mathrm{BF}$ on this paper. 


\section{References}

Andersson, J. O., T. Helander, L. H. Hoglund, P. F. Shi and B. Sundman (2002). "THERMOCALC \& DICTRA, computational tools for materials science." Calphad-Computer Coupling of Phase Diagrams and Thermochemistry 26(2): 273-312.

Bale, C. W., P. Chartrand, S. A. Degterov, G. Eriksson, K. Hack, R. Ben Mahfoud, J. Melançon, A. D. Pelton and S. Petersen (2002). "FactSage thermochemical software and databases." Calphad-Computer Coupling of Phase Diagrams and Thermochemistry 26(2): 189-228.

Bowen, N. (1913). "The Melting Phenomena of the Plagioclase Feldspars.” American Journal of Science 35: 577-599.

Bowen, N. and O. Anderson (1914). "The Binary System MgO-SiO 2 ." American Journal of Science 37: 487-500.

Bowen, N. and J.F. Schairer (1932) “The System, FeO - $\mathrm{SiO}_{2}$.”American Journal of Science 24: 177-213.

Bowen, N. and J.F. Schairer (1935). "The System, Magnesia-Ferrous Oxide-Silica." American Journal of Science 29: 153.

Bradley, J. P., H. J. Humecki and M. S. Germani (1992). “Combined Infrared and Analytical Electron Microscope Studies of Interplanetary Dust Particles.” The Astrophysical Journal 394: 643-651.

Campins, H. and E. V. Ryan (1989). “The Indentification of Crystalline Olivine in Cometary Silicates." The Astrophysical Journal 341: 1059-1066. 
Cater, E. D. (1979). "The Effusion Method at Age 69: Current State of the Art" in Characterization of High Temperature Vapors and Gasses Vol 1. (Hastie, J. W., ed), NBS Special Publication 561/1, Washington, D.C.

Chekhovskoi, D. V., A. V. Ivanisov, A. Y. Proskurnev and C. R. C. Press (1993).

IVTANTHERMO Database on Thermodynamic Properties of Individual Substances. NIST special database 5. Boca Raton, CRC Press.

Chestakov, D. A., D. H. Parker, and A. V. Baklanov. (2005) "Iron Monoxide Photodissociation". Journal of Chemical Physics 122: 84302-84302.

Copland, E. H. and N. S. Jacobson (2001). "Thermodynamic Activity Measurements with Knudsen Cell Mass Spectrometry." The Electrochemical Society Interface Summer: 28-31.

Copland, E. H. and N. S. Jacobson (2010). "Measuring Thermodynamic Properties of Metals and Alloys with Knudsen Effusion Mass Spectrometry.”

Copland, E. H., J. V. Auping and N. S. Jacobson (2013). "The Process of Developing a MultiCell KEMS Instrument." Proceedings of the Workshop on Knudsen Effusion Mass Spectrometry 46(1): 197-209.

Cruikshank, D. P. and W. K. Hartmann (1984). "The Meteorite-Asteroid Connection: Two Olivine-Rich Asteroids.” Science 223(4633): 281-283.

Dachs, E. and C.A. Geiger (2007). "Entropies of mixing and Subsolidus Phase Relations of Forsterite - Fayalite $\left(\mathrm{Mg}_{2} \mathrm{SiO}_{4}-\mathrm{Fe}_{2} \mathrm{SiO}_{4}\right)$ Solid Solution.” American Mineralogist 92: 699-702.

Decterov, S. A., I. H. Jung and A. D. Pelton (2002). "Thermodynamic modeling of the FeO$\mathrm{Fe}_{2} \mathrm{O}_{3}-\mathrm{MgO}-\mathrm{SiO}_{2}$ system." Journal of the American Ceramic Society 85(12): 2903-2910. 
Dohmen, R., S. Chakraborty, H. Palme and W. Rammansee (1998). "Solid-Solid Reactions Mediated by a Gas Phase: An Experimental Study of Reaction Progress and the Role of Surfaces in the System Olivine + Iron Metal.” American Mineralogist 83: 970-984.

Drowart, J. and P. Goldfinger (1967). "Investigation of Inorganic Systems at High Temperature by Mass Spectrometry." Angewandte Chemie-International Edition 6(7): 581-648.

Dressing, C. D., D. Charbonneau, X. Dumusque, S. Gettel, F. Pepe, A. C. Cameron, D. W. Latham, E. Molinari, S. Udry, L. Affer, A. S. Bonomo, L. A. Buchhave, R. Cosentino, P. Figueira, A. F. M. Fiorenzano, A. Harutyunyan, R. D. Haywood, J. A. Johnson, M. L.-Morales, C. Lovis, L. Malavolta, M. Mayor, G. Micela, F. Motalebi, V. Nascimbeni, D. F. Phillips, G. Piotto, D. Pollaco, D. Queloz, K. Rice, D. Sasselov, D. Ségransan, A. Sozzetti, A. Szentgyorgyi and C. Watson (2015). "The Mass if Kepler-93b and the Compositions of Terrestrial Planets." The Astrophysical Journal 800:135.

Drowart, J., C. Chatillon, J. Hastie, and D. Bonnell (2005). "High-Temperature Mass Spectrometry: Instrumental Techniques, Ionization Cross-Sections, Pressure Measurements, and Thermodynamic Data." Pure and Applied Chemistry 77(4): 683-737.

Fabrichnaya, O. (1998). "The Assessment of Thermodynamic Parameters for Solid Phases in the Fe-Mg-O and Fe-Mg-Si-O Systems." Calphad 22(1): 85-125.

Fabrichnaya, O. (2000). "Thermodynamic Modelling of Melting in the System FeO-MgO-SiO ${ }_{2}$ $\mathrm{O}_{2}$ at Pressure of 1 bar." Calphad 24(2): 113-131.

Fegley, B., Jr. and A.G.W. Cameron (1987). “A Vaporization Model for Iron/Silicate Fractionation in the Mercury Protoplanet." Earth and Planetary Science Letters 82: 207-222.

Fegley, B., Jr. and L. K. Schaefer (2014). Chemistry of the Earth's Earliest Atmosphere. Chapter 6.3 in The Atmosphere - History vol 13, J. Farquhar, D. Canfield and J. Kasting (ed), pp. 71-90, Treatise on Geochemistry, Elsevier Science. 
Field, F. H. and J. L. Franklin (2013). Electron impact phenomena: and the properties of gaseous ions, Academic Press.

Gail, H.-P. and E. Sedlmayr (2014). Physics and Chemistry of Circumstellar Dust Shells. New York, New York, Cambridge University Press.

Hildenbrand, D. L. (1975). “Thermochemistry of Molecular FeO, FeO' and FeO.” Chemical Physics Letters 34(2): 352-354.

Hoefen, T. M., R. N. Clark, J. L. Bandfield, M. D. Smith, J. C. Pearl and P. R. Christensen (2003). "Discovery of Olivine in the Nili Fossae Region of Mars.” Science 302: 627-630.

Hultgren, R., P. D. Desai, D. T. Hawkins, M. Gleiser and K. K. Kelley (1973). Selected Values of the Thermodynamic Properties of the Elements, DTIC Document.

Ito, Y., M. Ikoma, H. Kawahara, H. Nagahara, Y. Kawashima, and T. Nakamoto (2015).

"Theoretical Emission Spectra of Atmospheres of Hot Rocky Super-Earths." The Astrophysical Journal 801:144.

Kato, E. (1993). "Thermodynamic Studies of Metallurgical Systems by Mass Spectrometry." Journal of Mass Spectrometry Society of Japan 41(6): 297-316.

Keil, K., T. E. Bunch and M. Prinz (1970). "Mineralogy and Composition of Apollo 11 Lunar Samples." Proceedings of the Apollo 11 Lunar Science Conference 1: 561-598.

Kitayama, K. and T. Katsura (1968). "Activity Measurements in Orthosilicate and Metasilicate Solid Solutions. I. $\mathrm{Mg}_{2} \mathrm{SiO}_{4}-\mathrm{Fe}_{2} \mathrm{SiO}_{4}$ and $\mathrm{MgSiO}_{3}-\mathrm{FeSiO}_{3}$ at 1204 C." Bulletin of the Chemical Society of Japan 41(5): 1146-1151.

Kite, E. S., B. Fegley, Jr., L. Schaefer and E. Gaidos (2016). “Atmosphere-Interior Exchange on Hot, Rocky Exoplanets.” The Astrophysical Journal 828:80. 
Kojima, Y., M. Inouye and K. Sano (1969). "The Activity of the Iron Oxide in FeO-MgO-SiO 2 Slags at $1600{ }^{\circ} \mathrm{C} . "$ Arch Eisenhuttenwesen 40(1): 37-40.

Larimer, J.W. (1968). "Experimental Studies on the System $\mathrm{Fe}-\mathrm{MgO}-\mathrm{SiO}_{2}-\mathrm{O}_{2}$ and Their Bearing on the Petrology of Chondritic Meteorites. Geochimica et cosmochimica acta 32: 11871207.

Lee, K. N. and W. L. Worrell (1989). "The Oxidation of Iridium-Aluminum and IridiumHafnium Intermetallics at Temperatures above $1550{ }^{\circ} \mathrm{C}$." Oxidation of metals 32(5-6): 357-369.

Levin, R. D., S. G. Lias and S. United States. National Bureau of. (1982). "Ionization Potential and Appearance Potential Measurements, 1971-1981." from http://purl.access.gpo.gov/GPO/LPS113176.

Lodders, K. (2003) Solar System Abundances and Condensation Temperatures of the Elements. Astrophysical Journal 591: 1220-1247.

Lodders, K., H. Palme, and H.P. Gail (2009). Abundances of the Elements in the Solar System. Chapter 4.4 in Solar System vol 4B, J.E. Trumper (ed), pp. 712-770, Landolt - Bornstein Tables, Springer Verlag, Berlin.

Mann, J. B. (1967). "Ionization Cross Sections of Elements Calculated from Mean-Square Radii of Atomic Orbitals." Journal of Chemical Physics 46(5): 1646-1651.

Muan, A. (1967). Determination of Thermodynamic Properties of Silicates from Locations of Conjugation Lines in Ternary Systems. American Mineralogist 52: 797-804.

Murad, E. (1980). “Thermochemical Properties of Gaseous FeO and FeOH.” Journal of Chemical Physics 73: 1381-1385. 
Mysen, B.O, and I. Kushiro (1988). "Condensation, Evaporation, Melting, and Crystallization in the Primitive Solar Nebula: Experimental Data in the System $\mathrm{MgO}-\mathrm{SiO}_{2}-\mathrm{H}_{2} \mathrm{O}$ to $1.0 \times 10^{-9}$ bars and $1870{ }^{\circ} \mathrm{C}$ with Variable Oxygen Fugacity." American Mineralogist 73(1): 1-19.

Nafziger, R. H. and A. Muan (1967). "Equilibrium Phase Compositions and Thermodynamic Properties of Olivines and Pyroxenes in System MgO-FeO-SiO 2 ." American Mineralogist 52(910): 1364-1385.

Nagahara, H., I. Kushiro, B. O. Mysen and H. Meri (1988). "Experimental Vaporization and Condensation of Olivine Solid Solution." Nature 331(6156): 516-518.

Nagahara, H. and I. Kushiro (1989). Vaporization Experiments in the System Plagioclase Hydrogen. Proc NIPR Symposium Antarctic Meteorites 2: 235-251.

Nagahara, H. (1990). "Vaporization Experiments in the System Plagioclase - Hydrogen: 2. Composition of the Gas.” Lunar Planetary Science Conference 21: 837-838.

Nagahara, H., I. Kushiro, B.O. Mysen (1993). Vaporization and Condensation of Chondritic Materials - Experimental Studies. In Primitive Solar Nebula and Origin of Planets, ed. H. Oya, pp. 427-446, Terra Scientific Publishing, Tokyo.

Nagahara, H., I. Kushiro and B. O. Mysen (1994). "Evaporation of olivine: Low pressure phase Relations of the Olivine System and Its Implication for the Origin of Chondritic Components in the Solar Nebula." Geochimica et Cosmochimica Acta 58(8): 1951-1963.

Navrotsky A. (1978). “Thermodynamics of Element Partitioning: (1) Systematics of Thansition Metals in Crystalline and Molten Silicates and (2) Defect Chemistry and “The Henry's Law Problem"."Geochimica et Cosmochimica Acta 42: 887-902.

Nguyen, A. N. and E. Zinner (2004). "Discovery of Ancient Silicate Stardust in a Meteorite." Science 303:1496-1499. 
Ozawa, H. and H. Nagahara (2000). "Kinetics of Diffusion-Controlled Evaporation of Fe-Mg Olivine: Experimental Study and Implication for Stability of Fe-rich Olivine in the Solar Nebula." Geochimica et Cosmochimica Acta 64(5): 939-955.

Pahlevan, K., D. J. Stevenson and J. M. Eiler (2011). “ Chemical Fractionation in the Silicate Vapor Atmosphere of the Earth.” Earth and Planetary Science Letters 301: 433-443.

Palme, H. and H. StC. O’Neill (2014). "Cosmochemical Estimates of Mantle Composition.” Chapter 3.1 in Treatise on Geochemistry $2^{\text {nd }}$ ed., Elsevier, Amsterdam, Netherlands.

Pauling, L. (1960). The Nature of the Chemical Bond, Cornell university press Ithaca, NY.

Piacente, V., J. Matousek, M. Spoliti and V. Dipaolo (1975). "Mass-Spectrometric Investigation of Olivine Vaporization Process." Silikaty 19(4): 289-300.

Plante, E. R., J. W. Hastie and M. Kowalska (1992). "Activity of FeO in the FeO-MgO-SiO 2 System Determined by High-Temperature Mass-Spectrometry." Isij International 32(12): 12761279.

Preston-Thomas, H. (1990). "International Temperature Scale of 1990 (ITS-90)." Metrologia 27: 3-10.

Sakawa, M., S. Whiteway and C. Masson (1976). "Activities of FeO in the Ternary System $\mathrm{SiO}_{2}$ $\mathrm{MgO}-\mathrm{FeO}$ and Constitution of $\mathrm{SiO}_{2}$." Tetsu to Hagane 62: 176-181.

Saxena, S., N. Chatterjee, Y. Fei and G. Shen (1993). Thermodynamic Data on Oxides and Silicates: An Assessed Data Set Based on Thermochemistry and High Pressure Phase Equilibrium, 428 p, Springer-Verlag, Berlin. 
Schaefer, L. and B. Fegley, Jr. (2004). "A Thermodynamic Model of High Temperature Lava Vaporization on Io. Icarus 169: 216-241.

Schaefer, L. and B. Fegley, Jr. (2009) Chemistry of Silicate Atmospheres of Evaporating SuperEarths. Astrophysical Journal 703: L113-L117.

Smoes, S., and J. Drowart (1984). "Determination of the Dissociation Energies of Gaseous Iron Monoxide and Manganese Monoxide by the Mass Spectrometric Knudsen Cell Method.” Modern High Temperature Science, pp 31-52, Humana Press.

Stebbins, J.F. and I.S.E. Carmichael (1984). "The Heat of Fusion of Fayalite.” American Mineralogist 69(3-4): 292-297.

Stolyarova, V. L., G. A. Semenov and J. H. Beynon (1994). Mass spectrometric study of the vaporization of oxide systems. Chichester; New York, Wiley.

Swierczynski, D., C. Courson, L. Bedel, A. Kiennemann and J. Guille (2006). "Characterization of Ni-Fe/MgO/Olivine Catalyst for Fluidized Bed Steam Gasification of Biomass." Chemistry of Materials 18(17): 4025-4032.

von Seckendorff, V. and H. S. C. O'Neill (1993). "An Experimental Study of Fe-Mg Partitioning Between Olivine and Orthopyroxene at 1173, 1273 and $1423 \mathrm{~K}$ and 1.6 GPa." Contributions to Mineralogy and Petrology 113(2): 196-207.

Wood, B. and O. Kleppa (1981). "Thermochemistry of Forsterite-Fayalite Olivine Solutions." Geochimica et Cosmochimica Acta 45(4): 529-534.

Woolf, N. J. and E. P. Ney (1969). "Circumstellar Infrared Emission from Cool Stars." The Astrophysical Journal 55: L181-L184. 
Wriedt, H. A. (1991). “The Fe-O (Iron-Oxygen) System.” Journal of Phase Equilibria 12(2):

170-200.

Wu, P., G. Eriksson, A. D. Pelton and M. Blander (1993). "Prediction of the Thermodynamic

Properties and Phase Diagrams of Silicate Systems-Evaluation of the FeO-MgO-SiO $2 \mathrm{System}^{\text {." }}$

ISIJ International 33(1): 26-35.

Table 1. Chemical composition of the olivine powder samples before and after KEMS.

\begin{tabular}{lcccc}
\hline & \multicolumn{3}{c}{ Weight $(\%)^{\dagger}$} \\
\cline { 2 - 5 } Element/Oxide & $\begin{array}{c}\text { Olivine } \\
\text { as- } \\
\text { received }\end{array}$ & $\begin{array}{c}\text { Olivine } \\
\text { Before }\end{array}$ & $\begin{array}{c}\text { After } \\
\text { KEMS }\end{array}$ & $\begin{array}{c}\text { After } \\
\text { KEMS }^{\dagger \dagger} \\
\text { Abelow Melting } \\
\text { Above Melting }\end{array}$ \\
\hline $\mathrm{Mg}$ & $30(2)$ & $30(2)$ & $32(2)$ & $33.1(6)$ \\
$\mathrm{Fe}$ & $5.0(3)$ & $3.6(2)$ & $2.9(1)$ & $0.16(1)$ \\
$\mathrm{Si}$ & $20(1)$ & $17.0(9)$ & $17.2(9)$ & $27.9(5)$ \\
$\mathrm{MgO}$ & $50(4)$ & $55(4)$ & $57(4)$ & $48(1)$ \\
$\mathrm{FeO}$ & $6.5(5)$ & $5.1(4)$ & $4.0(2)$ & $0.18(1)$ \\
$\mathrm{SiO}$ & $43(3)$ & $40(3)$ & $39(3)$ & $52(1)$ \\
$\mathrm{Mole}(\%) *$ & & & & $100(2)$ \\
$\mathrm{Mg}$, forsterite & $93(5)$ & $95(5)$ & $96(5)$ & $0.21(1)$ \\
$\mathrm{Fe}$, fayalite & $6.7(3)$ & $4.9(2)$ & $3.9(2)$ & \\
\hline
\end{tabular}

${ }^{\dagger}$ Uncertainties of the analyses are given in parentheses. $* \mathrm{Mg}$, forsterite mole $(\%)=$ Weight $\%{ }_{\mathrm{Mg}} /(24.305 \cdot$ total mol $) \cdot 100$. Fe, fayalite mole $(\%)=$ Weight $\%_{\mathrm{Mg}} \cdot /(55.845 \cdot$ total mol $) \cdot 100$. Total mol $=\left(\right.$ Weight $\left.\%_{\mathrm{Fe}} / 55.845\right)+\left(\right.$ Weightt $\left.\%_{\mathrm{Mg}} / 24.305\right)$. Total sum of the Al, Ca, Co, Mn and Ni contents are less than 0.5 weight $\%{ }^{t+}$ EPMA. According to X-ray elemental mapping, iron is distributed in the fosterite rich olivine and protoenstatite phases.

Table 2. Vapor species of the olivine sample detected by KEMS and their appearance potentials $(\mathrm{eV})$.

\begin{tabular}{lcc}
\hline \multirow{2}{*}{ Vapor Species } & \multicolumn{2}{c}{ Appearance Potential (eV) } \\
\cline { 2 - 3 } & *This work & (Levin et al. 1982) \\
\hline $\mathrm{Mg}^{+}$ & $7.46 \pm 1.81$ & $7.63 \pm 0.08$ \\
$\mathrm{Fe}^{+}$ & $7.18 \pm 1.81$ & $7.7 \pm 0.2$ \\
$\mathrm{FeO}^{+}$ & $8.25 \pm 1.5$ & $8.71 \pm 0.10$ \\
$\mathrm{SiO}^{+}$ & $10.60 \pm 1.83$ & $10.53 \pm 0.02$ \\
$\mathrm{O}^{+}$ & $14.9 \pm 1.93$ & $14.0 \pm 0.5$ \\
$\mathrm{O}_{2}^{+}$ & $17.22 \pm 2.88$ & $18.69 \pm 0.04$ \\
\hline
\end{tabular}

*Extra digit is retained to prevent round-off errors. 
Table 3. Partial molar enthalpies of $\mathrm{MgO}$, ' $\mathrm{FeO}$ ', and $\mathrm{SiO}_{2}$ as determined from activity dependence on inverse temperature.

\begin{tabular}{lcc}
\hline Component & This Study & $\begin{array}{c}\text { Calculated from } \\
\text { Fabrichnaya Database }\end{array}$ \\
\hline $\mathrm{MgO}$ & $-97.4 \pm 4.8$ & -48.0 \\
$' \mathrm{FeO}$ & $-47.7 \pm 4.1$ & -35.7 \\
$\mathrm{SiO}_{2}$ & $98.0 \pm 3.6$ & 70.73 \\
\hline
\end{tabular}

Table 4. Thermochemical data for olivine vaporization

\begin{tabular}{|c|c|c|c|}
\hline Component & $\Delta \mathbf{H}_{\mathrm{vap}}(\mathrm{kJ} / \mathrm{mol})$ & $\Delta \mathbf{S}_{\mathrm{vap}}(\mathrm{J} / \mathrm{K} \cdot \mathrm{mol})$ & Reference \\
\hline \multicolumn{4}{|c|}{ Forsterite (solid) } \\
\hline regular $\mathrm{Fo}_{95} \mathrm{Fa}_{5}$ & $585 \pm 4$ & $183 \pm 2$ & this work \\
\hline ideal $\mathrm{Fo}_{95} \mathrm{Fa}_{5}$ & $585 \pm 4$ & $183 \pm 2$ & this work \\
\hline ideal $\mathrm{Fo}_{90} \mathrm{Fa}_{10}$ & $548 \pm 13$ & $233 \pm 13$ & Piacente et al. 1975 \\
\hline $\mathrm{Fo}_{100}$ & $543 \pm 33$ & $169 \pm 21$ & Nagahara et al. 1994 \\
\hline $\mathrm{Fo}_{100}$ & $640 \pm 36$ & $210 \pm 54$ & Mysen \& Kushiro 1988 \\
\hline \multicolumn{4}{|c|}{ Fayalite (liquid) } \\
\hline regular $\mathrm{Fo}_{95} \mathrm{Fa}_{5}$ & $431 \pm 3$ & $156 \pm 2$ & this work \\
\hline ideal $\mathrm{Fo}_{95} \mathrm{Fa}_{5}$ & $428 \pm 3$ & $153 \pm 2$ & this work \\
\hline ideal $\mathrm{Fo}_{90} \mathrm{Fa}_{10}$ & $410 \pm 15$ & $179 \pm 14$ & Piacente et al. 1975 \\
\hline $\mathrm{Fa}_{100}$ & $412 \pm 7$ & $139 \pm 4$ & Nagahara et al. 1994 \\
\hline
\end{tabular}

Table 5. (Fe/Mg) Atomic ratio in silicate vapor atmospheres of HRE

\begin{tabular}{ccc}
\hline Planet & Surface T $(\mathbf{K})^{\mathbf{a}}$ & $\mathbf{F e} / \mathbf{M g}^{\mathbf{c}}$ \\
\hline Kepler 36b & 1476 & 769 \\
Kepler 93b & 1569 & 360 \\
KOI-2700b & 1780 & 86 \\
K2-22b & 2135 & 15 \\
CoRoT-7b & 2425 & 5.1 \\
early Earth & $2500^{\mathrm{b}}$ & 4.0 \\
55 Cnc e & 2671 & 2.5 \\
Kepler 10b & 3007 & 1.1 \\
Kepler 78b & 3056 & 1.0 \\
early Earth & $3500^{\mathrm{b}}$ & 0.46 \\
\hline
\end{tabular}

${ }^{a}$ Sub-stellar temperatures of exoplanets from Kite et al. (2016)

${ }^{b}$ Pahlevan et al. (2011) give $2500-2500 \mathrm{~K}$ for temperature of the Earth's silicate vapor atmosphere after the Moon-forming impact.

${ }^{\mathrm{c}}$ From our modeling, see section 4.7 for a discussion. 


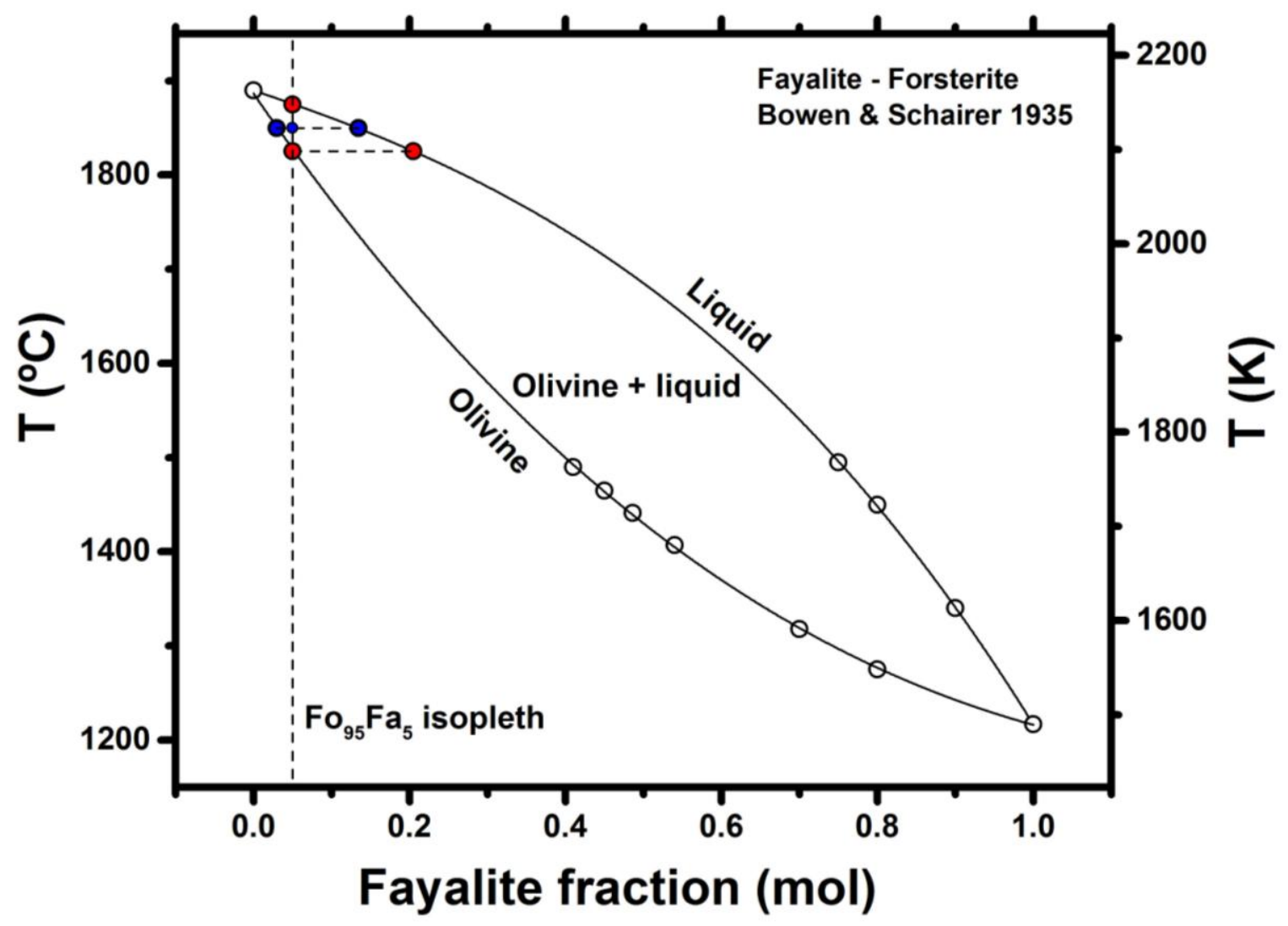

Figure 1(a). Calculated pseudo-binary (Fo-Fa) phase diagram (Bowen and Schairer, 1935) 
2015.09.25.10.41.58

USER: MGO, FEO, SIO2, FE

$N=1, P=1.01325 E 5, T=1400, X(F E)=1 E-5$

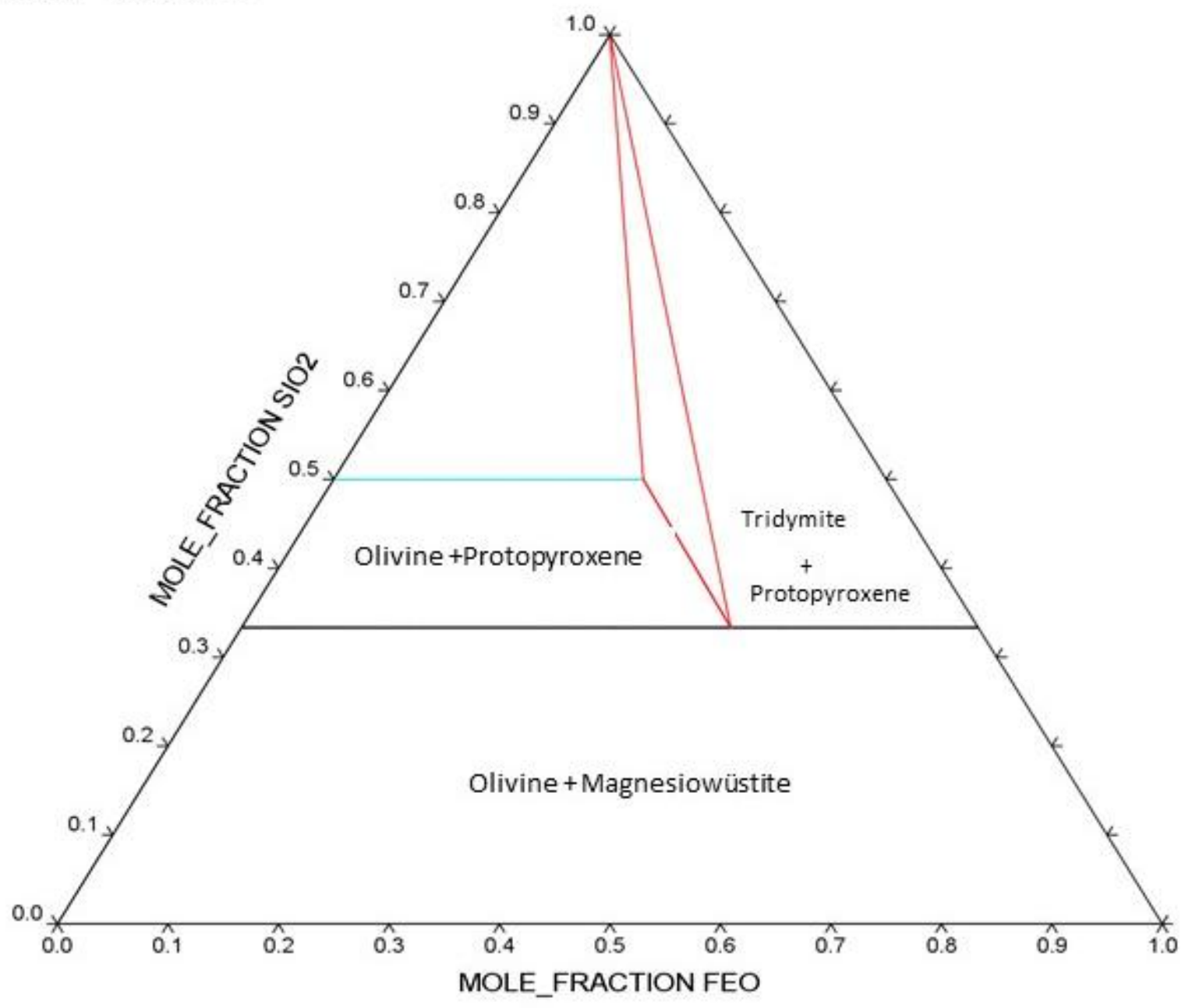

Figure 1(b). Calculated pseudo-ternary $\mathrm{MgO}$ - ' $\mathrm{FeO}$ '- $\mathrm{SiO}_{2}$ phase diagram. 


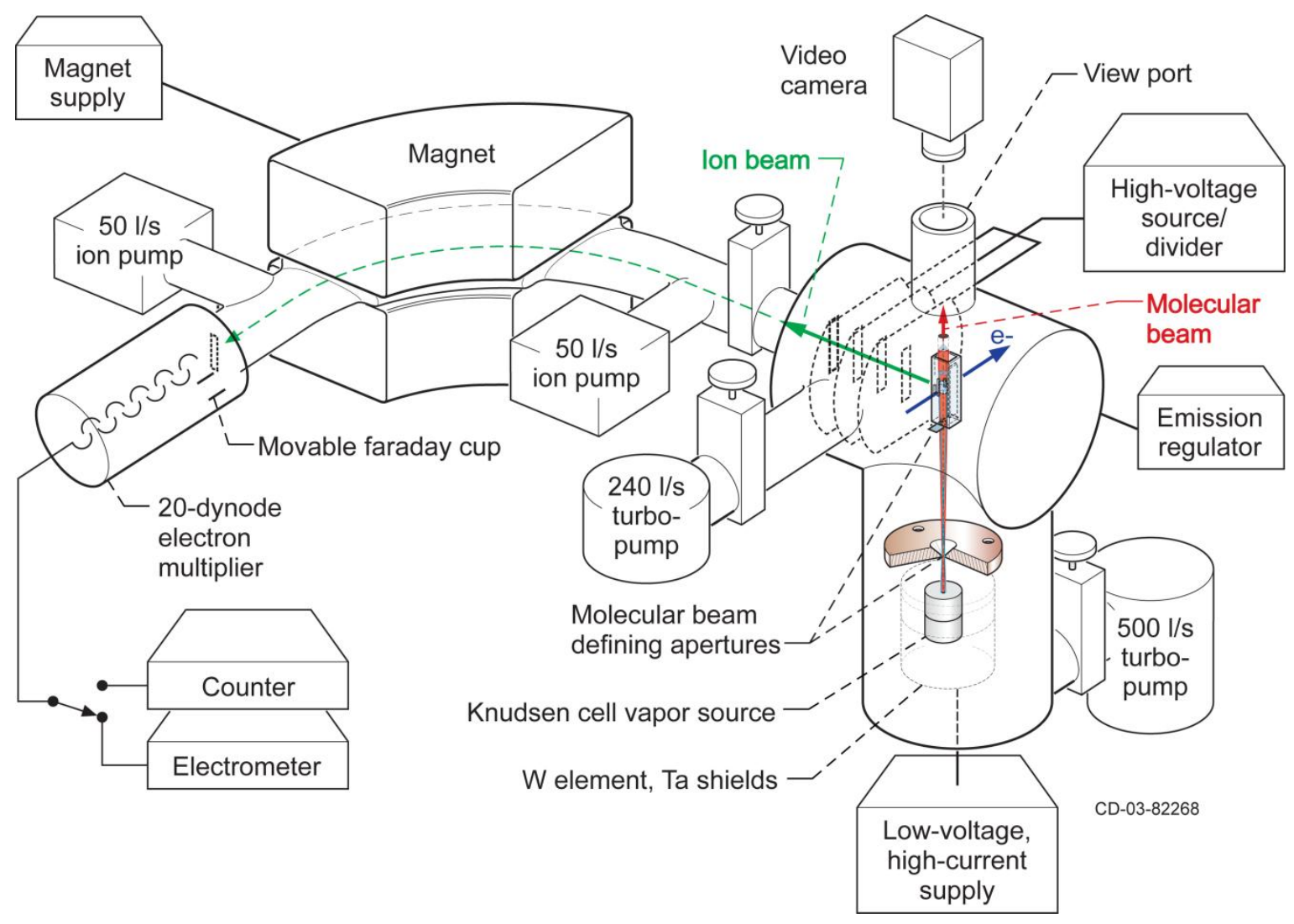

Figure 2. Knudsen Effusion Mass Spectrometer (Copland and Jacobson 2010). 


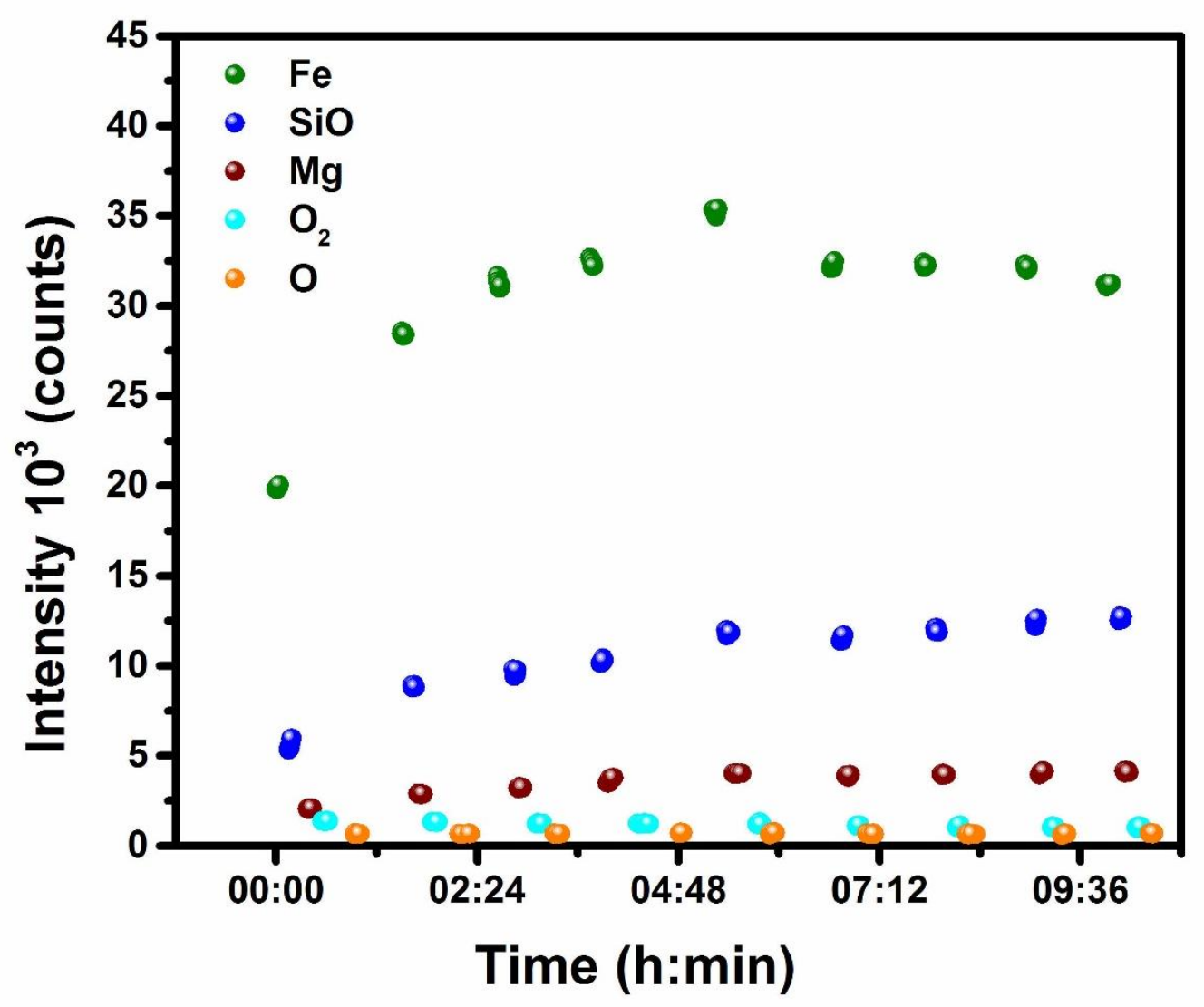

Figure 3. Dependence of the ion intensities of the vapor species of olivine over time at $1890 \mathrm{~K}$. 


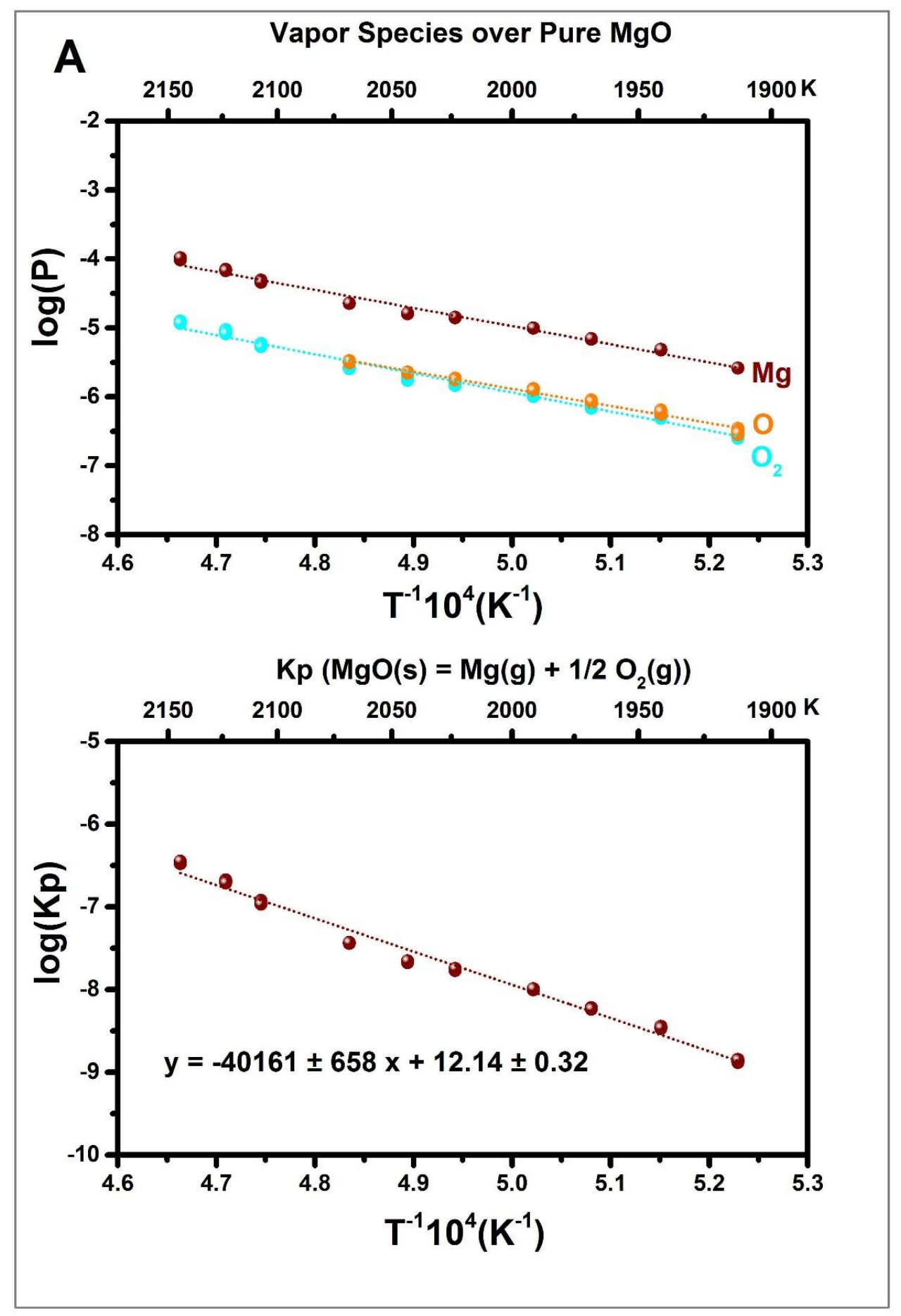




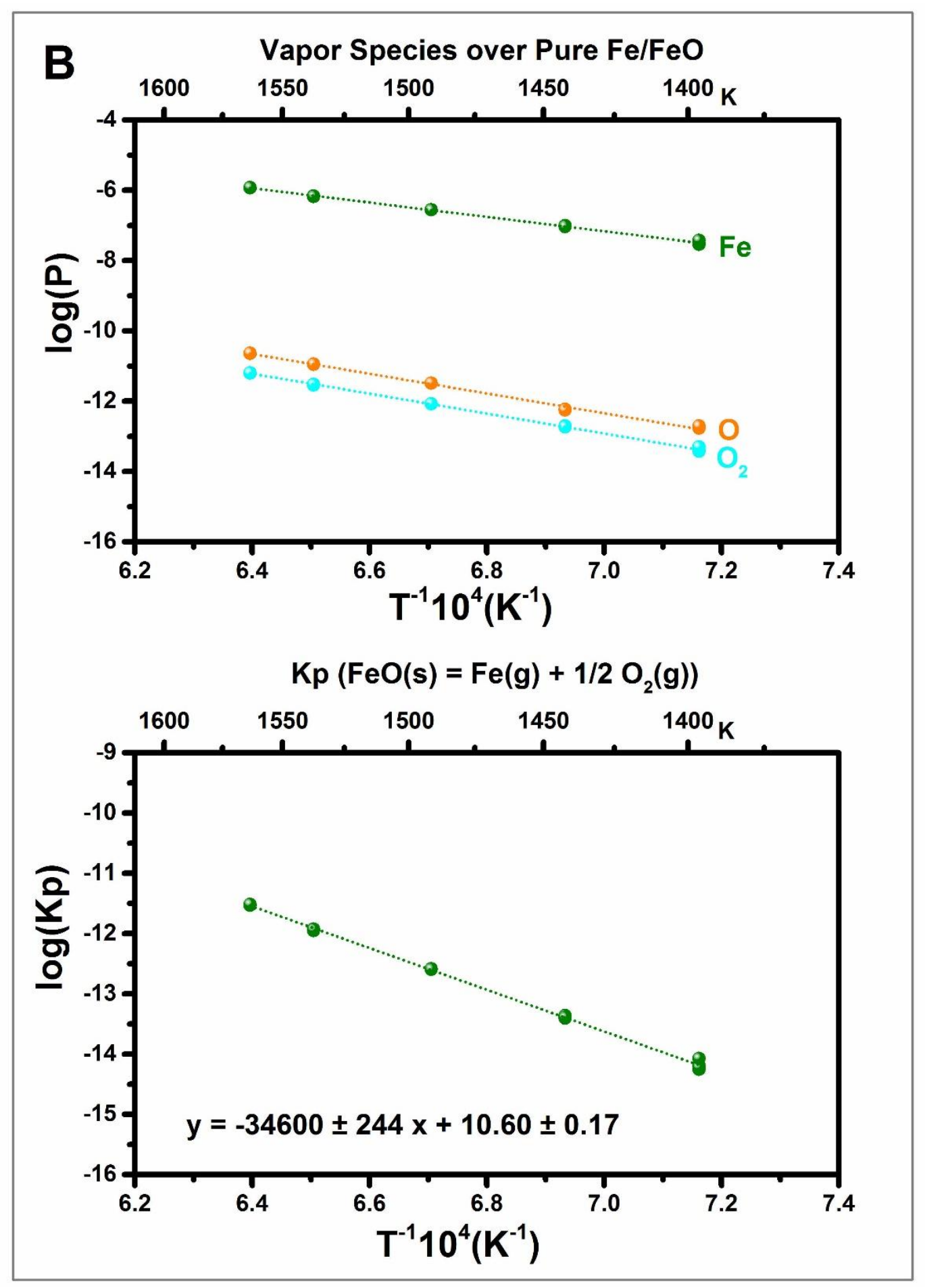




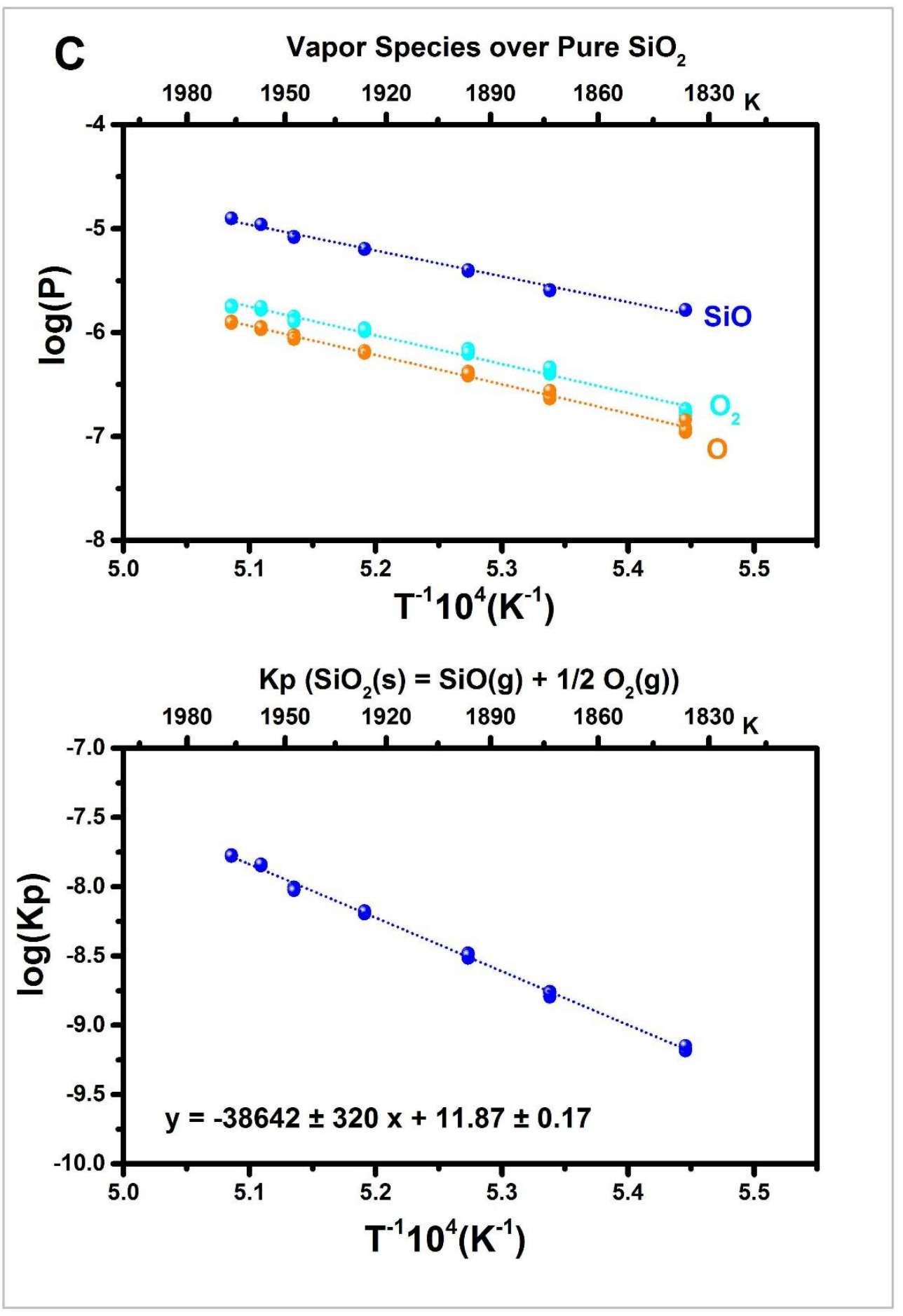

Figure 4. Temperature dependence of the ion intensity ratios of the vapor species above the reference materials - (A) $\mathrm{MgO}$, (B) $\mathrm{Fe} / \mathrm{FeO}$, and (C) $\mathrm{SiO}_{2}$. Note that for $\mathrm{Fe} / \mathrm{FeO}$ the oxygen partial pressures are calculated. Equilibrium constants are calculated for each reaction (3-5) and also plotted. 


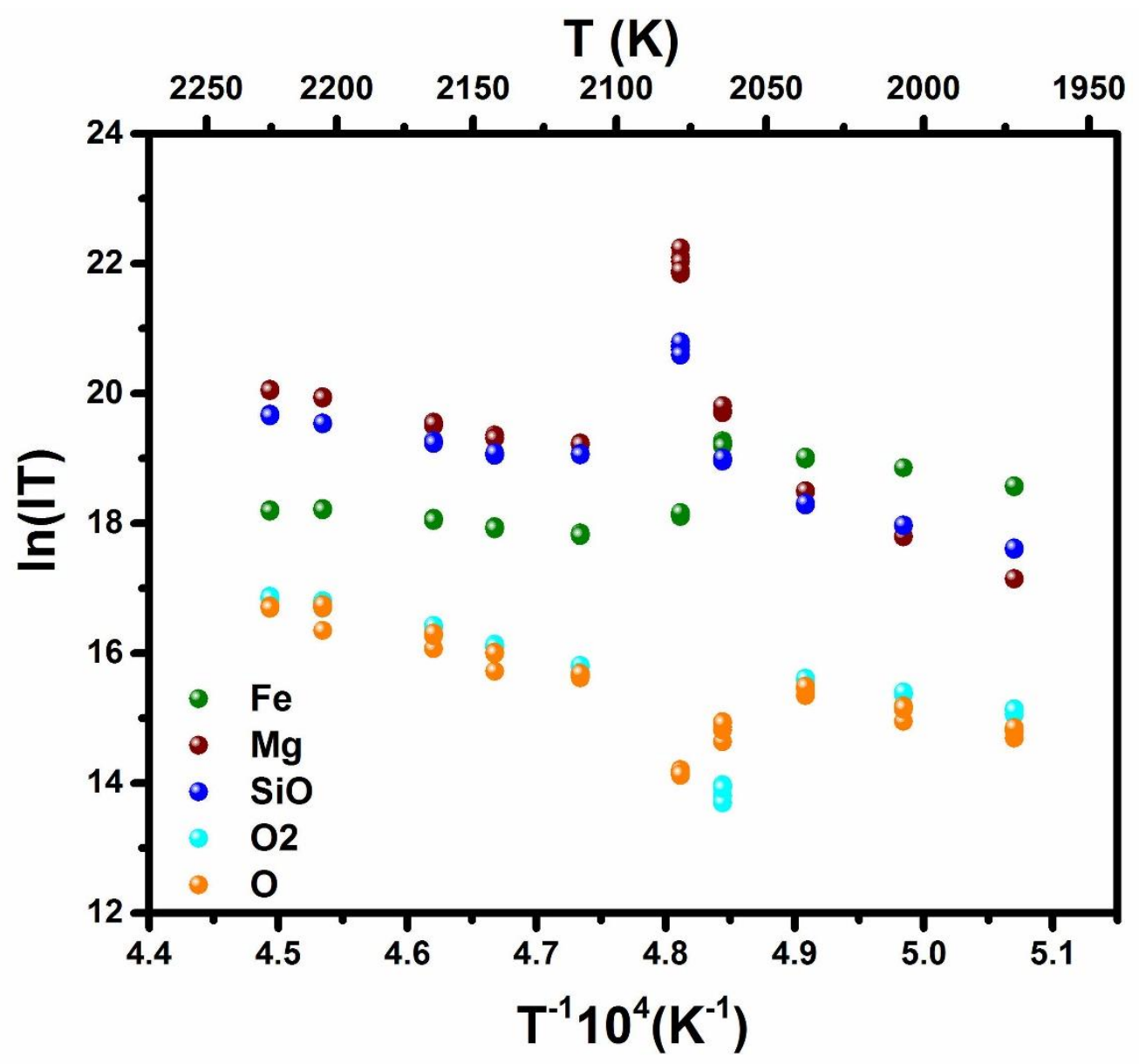

Figure 5. Temperature dependence of the ion intensities for each species through the melting point. On-set of melting is $\sim 2050 \mathrm{~K}$. Energy of ionizing electrons was $26 \mathrm{eV}$. 


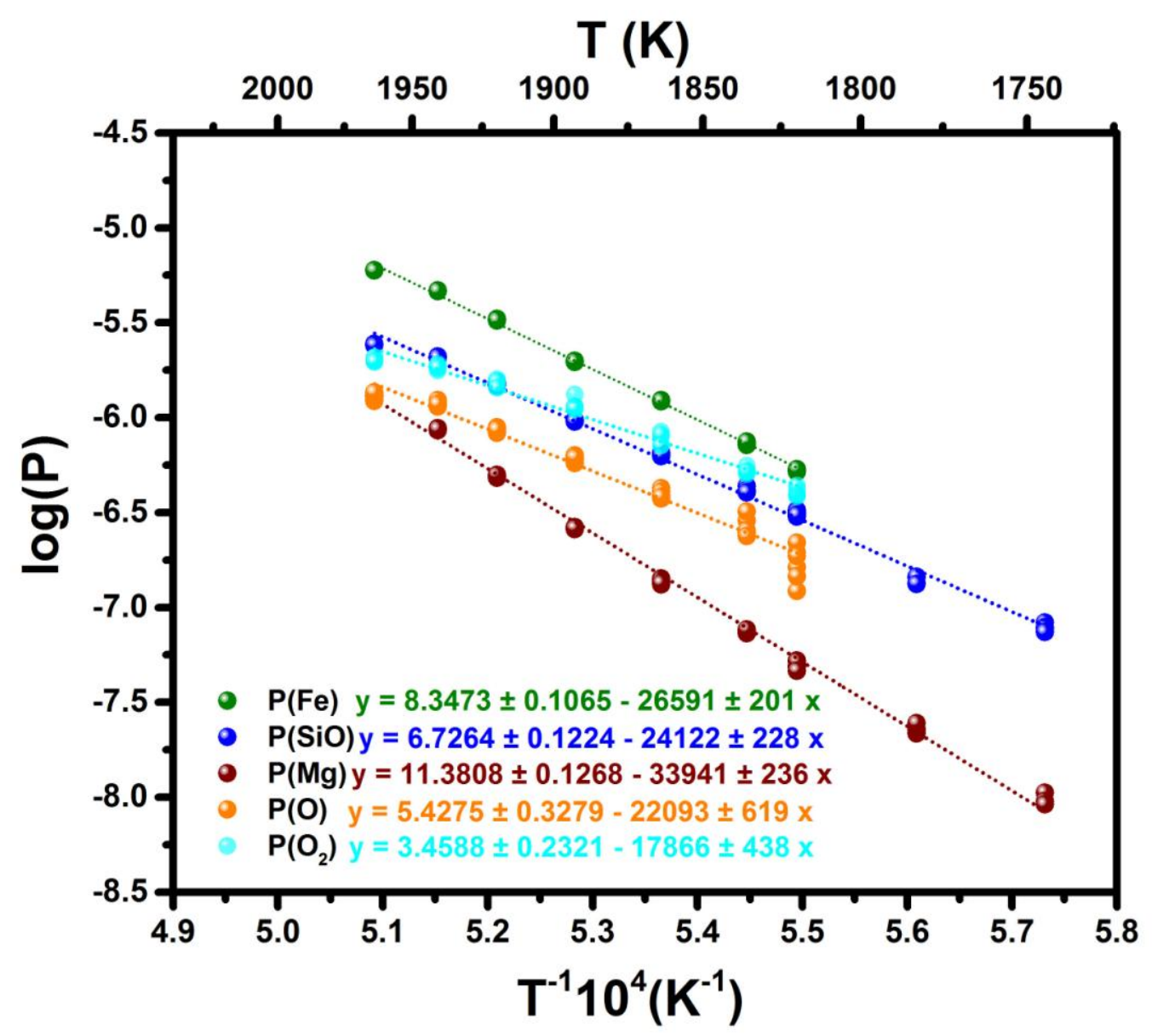

Figure 6. Dependence of the partial pressures of the species above olivine with inverse temperature for olivine $\left(\mathrm{Fo}_{95} \mathrm{Fa}_{5}\right)$. Energy of ionizing electron $16.5 \mathrm{eV}$. 


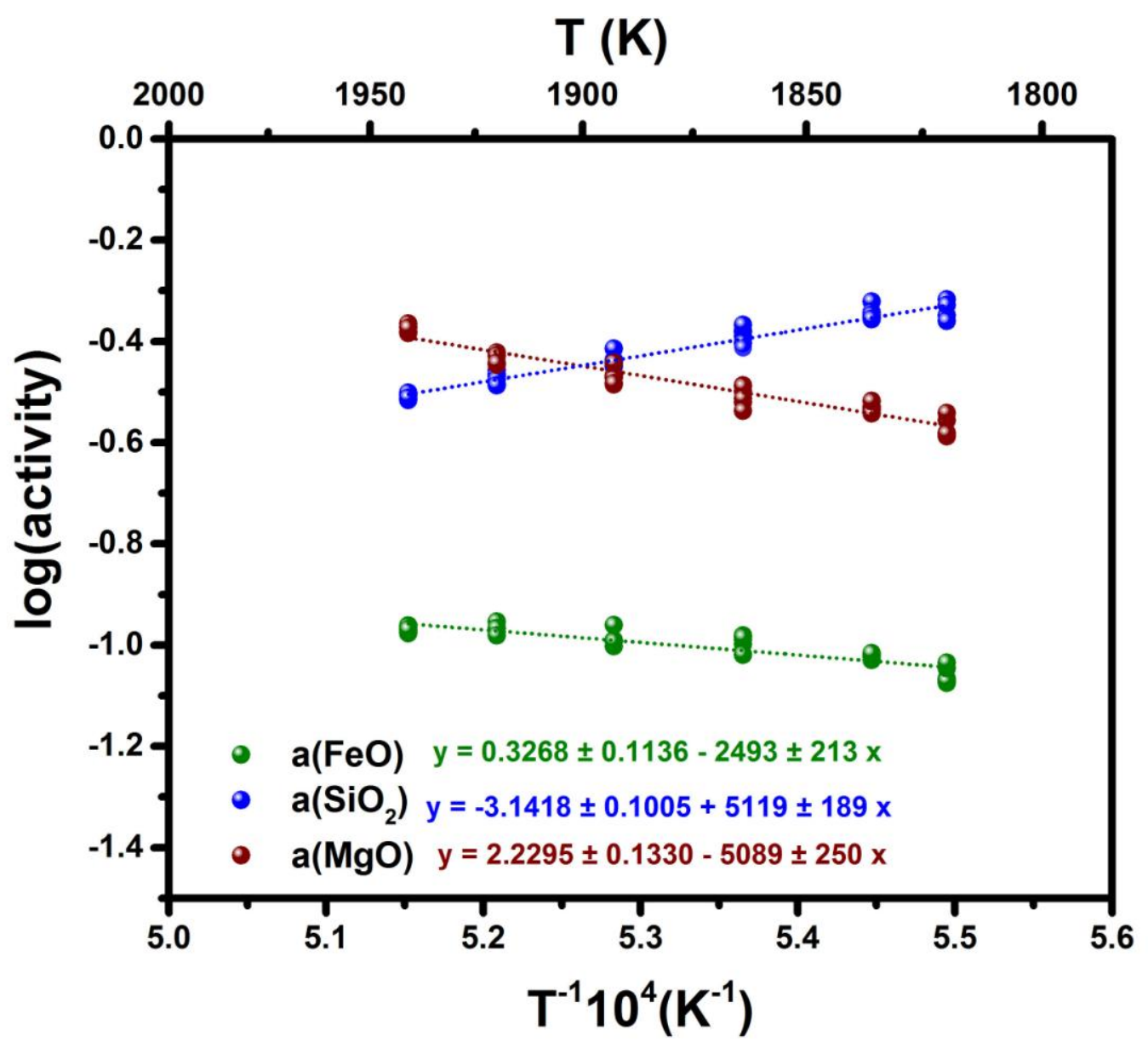

Figure 7. Thermodynamic activities for $\mathrm{FeO}, \mathrm{MgO}$, and $\mathrm{SiO}_{2}$ in olivine as a function of inverse temperature. 


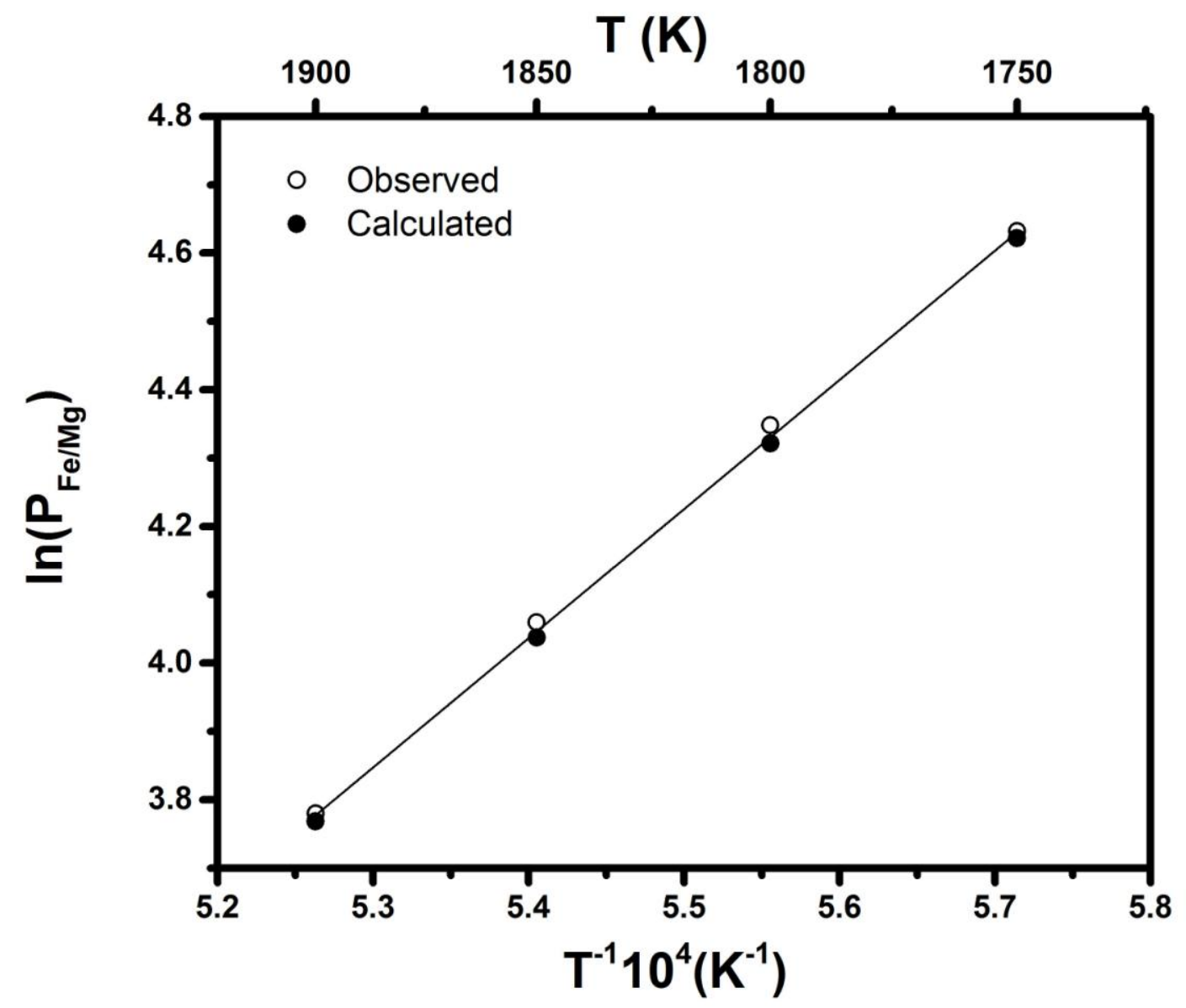

Figure 8. Plot of pressure ratios of $\mathrm{Fe}$ to $\mathrm{Mg}$ versus inverse temperature. 

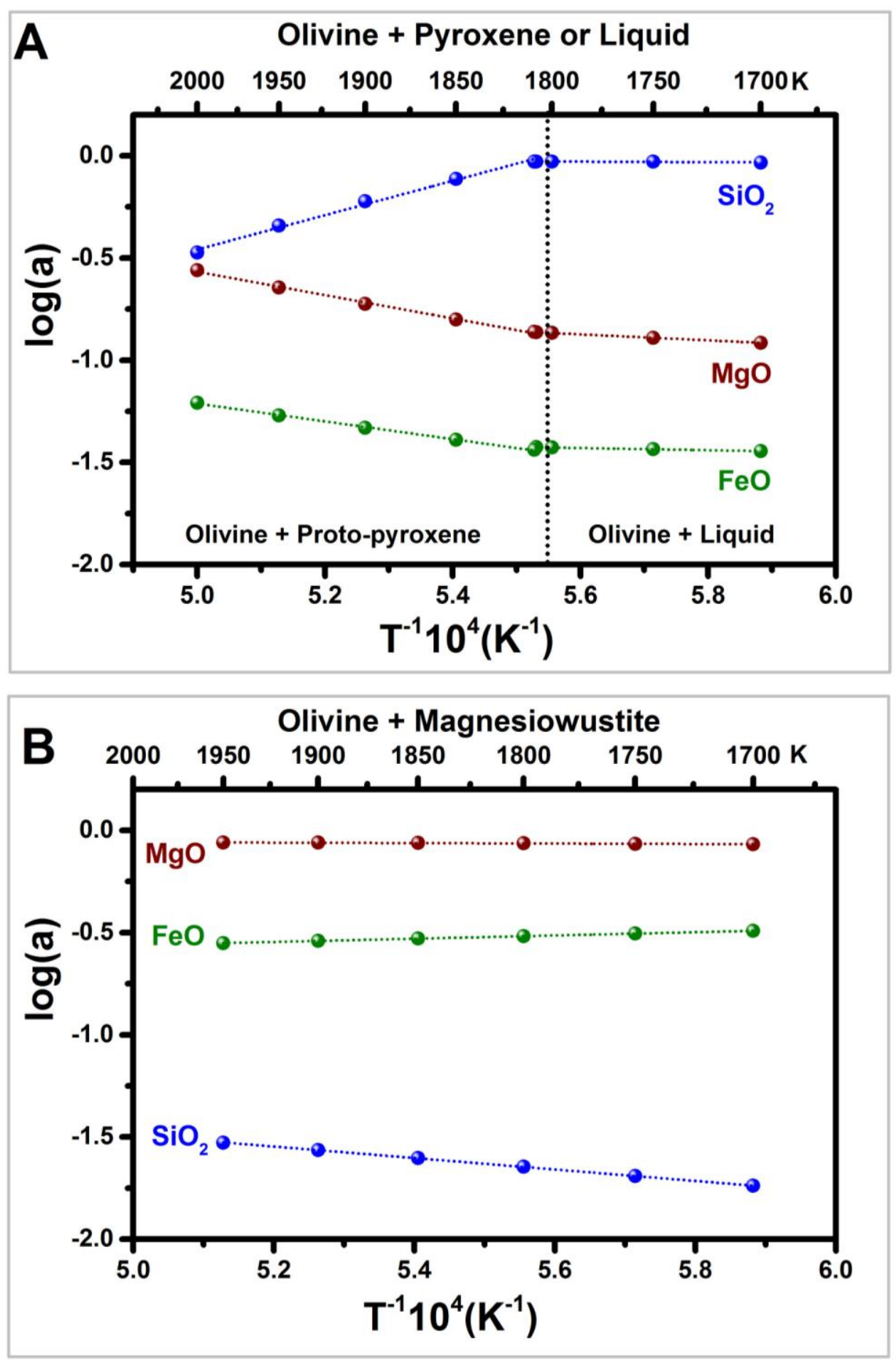

Figure 9. Calculations of component activities in $\left(\mathrm{Fo}_{95} \mathrm{Fa}_{5}\right)$ for $(\mathrm{A})$ olivine + protoproxene or liquid and (B) olivine + magnesiowüstite using the database of Fabrichnaya. (Fabrichnaya 1998) 


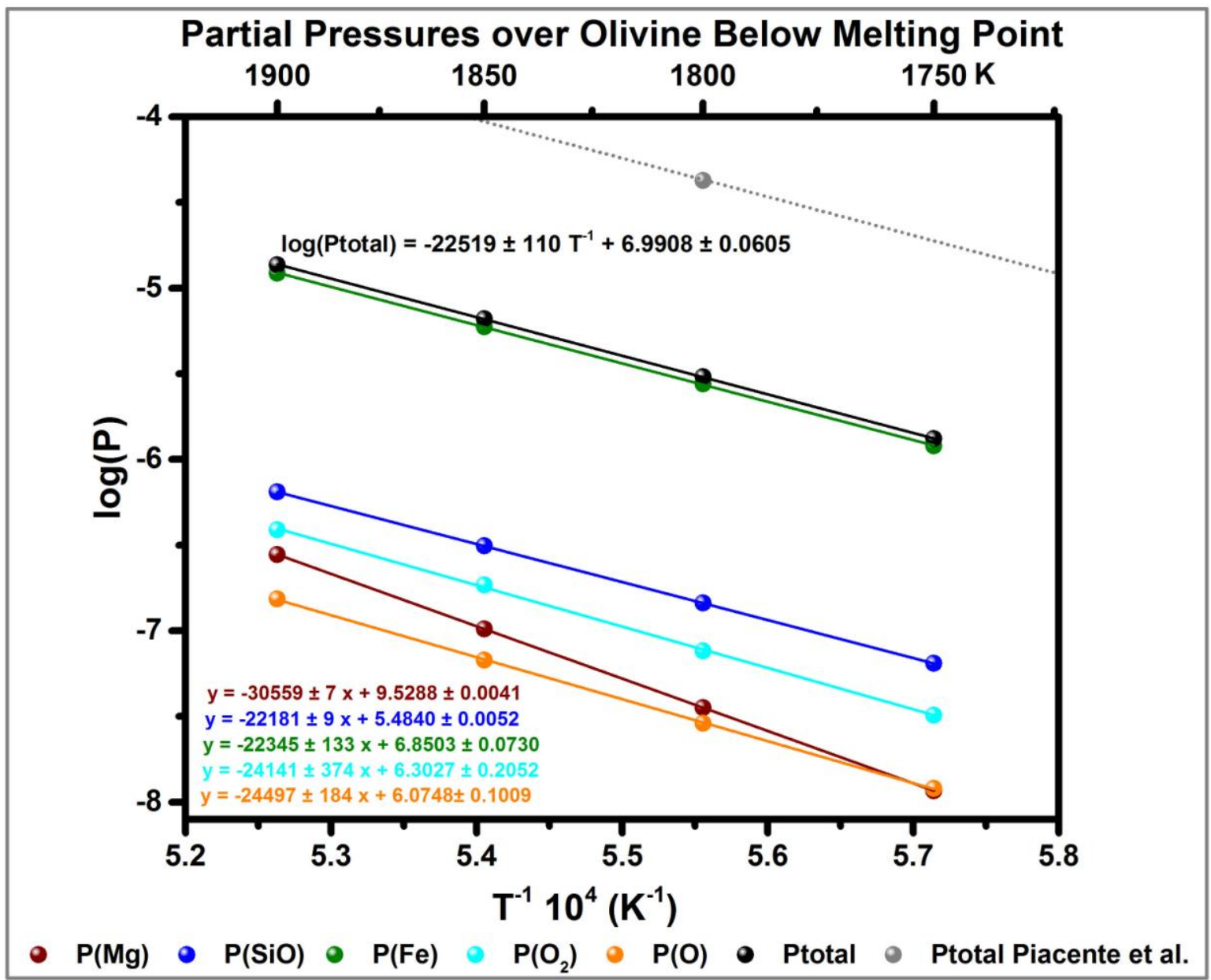

Figure 10. Total vapor pressure over $\mathrm{F}_{95} \mathrm{Fa}_{5}$ below melting point. 


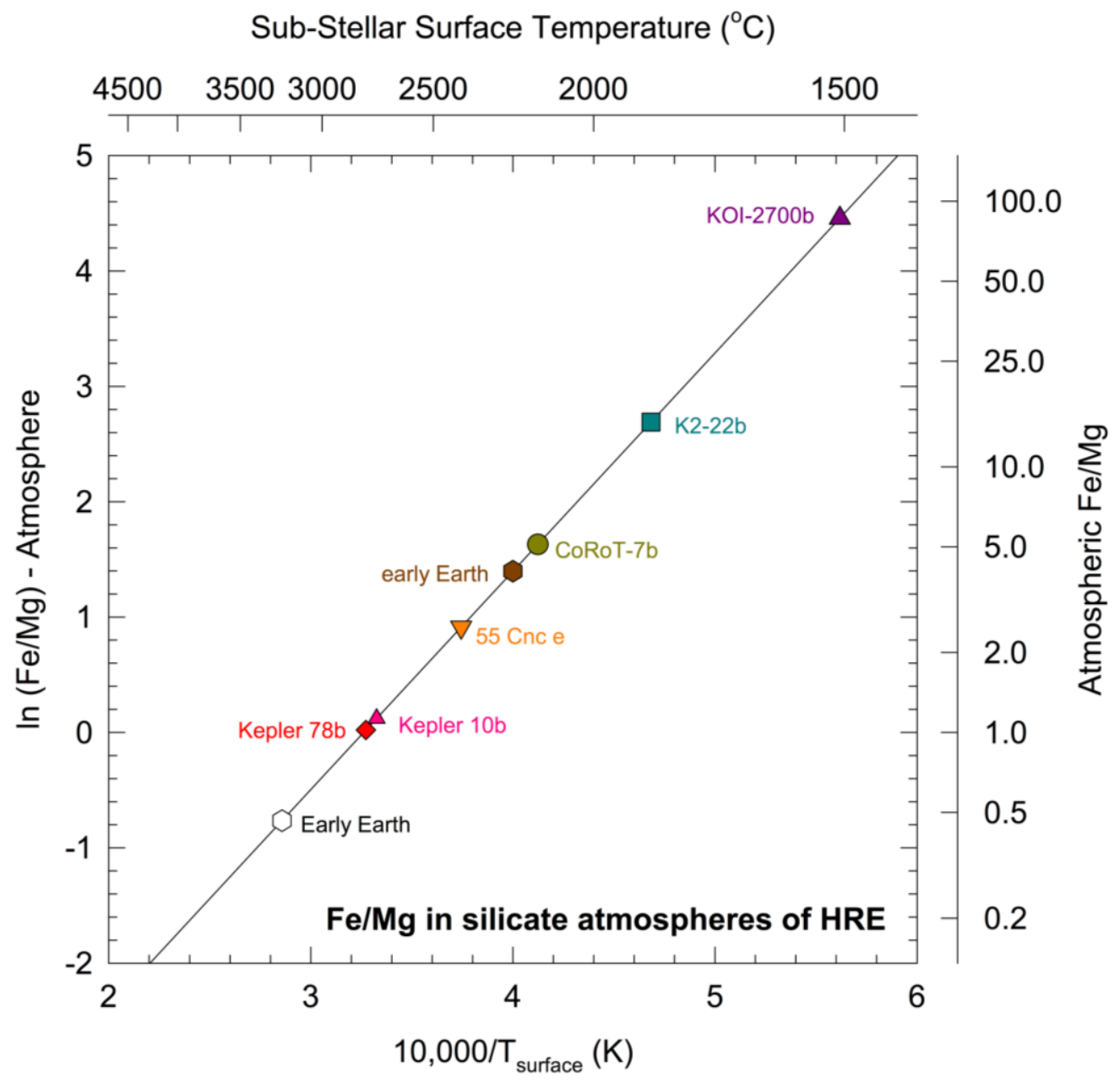

Figure 11. Natural logarithm of $\mathrm{Fe} / \mathrm{Mg}$ atomic ratio versus inverse temperature in silicate vapor atmospheres of HRE.

\section{Supplementary Material}

\section{Materials and Characterization}

The olivine used in this work is from one of the dunite deposits on the west coast of Norway that is used for making refractory brick for metallurgical industry and was provided by Miller \& Co., Chicago, IL. Goldschmidt (1938) describes these deposits and gives some typical chemical and mineralogical analyses. The composition, phase evolution and thermal behavior of the olivine samples were probed by X-ray powder diffraction (XRD), electron probe microanalysis (EPMA) and by inductively coupled plasma optical emission spectroscopy (ICP-OES). Before Knudsen 
effusion mass spectrometry, the olivine powder samples were placed in an iridium-enclosed graphite Knudsen cell and heat treated in a vacuum furnace (Oxy-Gon industries, Inc, Epsom, New Hampshire) at $1580{ }^{\circ} \mathrm{C}$ for $10 \mathrm{~h}$ in order to eliminate secondary phases and other impurities.

Conventional powder X-ray diffraction analysis, Rietveld refinement, and qualitative assessments of the crystallite sizes of the as-received olivine sample were made from diffraction patterns gathered on a Bruker D8 Discover diffractometer (Bruker-AXS GmbH, Karlsruhe, Germany) equipped with a graphite beam monochrometer, a $0.5 \mathrm{~mm}$ diameter monocapillary collimator and an Vantec 500 area detector, operated at an accelerating voltage of $40 \mathrm{kV}$ and an emission current of $40 \mathrm{~mA}$ with $\mathrm{CuK} \alpha$ radiation $(\lambda=0.15406 \mathrm{~nm})$. Data were gathered between 13.2 and $46^{\circ} 2 \theta$ with $60 \mathrm{~s}$ exposure time with a stationary sample holder. When initial data indicated large crystallite sizes, the sample was ground for $10 \mathrm{~min}$ in isopropyl alcohol in a McCrone micronizing mill (McCrone, Westmont, IL) with agate milling elements in order to reduce the crystallite size for improved counting statistics.

After the vaporization experiments, the olivine samples were ground in an agate mortar and the data were acquired from 10 to $120^{\circ} 2 \theta$ with a step size of $0.015^{\circ}$ and a collection time of $2.5 \mathrm{~s}$ $\mathrm{step}^{-1}$. The samples were rotated at $30 \mathrm{rpm}$. For the pristine olivine sample ground in the micronizing mill, crystalline phases were identified using Highscore software (Panalytical, Westborough, MA) equipped with the International Centre for Diffraction Data (ICCD) Powder Diffraction File (PDF-4+). Phase content was calculated from diffraction peak broadening using a whole profile fitting procedure (Rietveld refinement) as implemented in the Topas 4.2 software package (Bruker-AXS GmbH, Carlsruhe, Germany). For the post-Knudsen vaporization samples, crystalline phases were identified using Jade 2010 v.3 software (Materials Data Inc, Livermore, CA) equipped with the International Centre for Diffraction Data (ICDD) Powder Diffraction File (PDF-4+, 2013). Quantitative phase analysis (QPA) was performed using a whole pattern fitting procedure (Rietveld refinement) as implemented in the Jade $2010 \mathrm{v} .3$ software package.

The composition of the as-received olivine samples, and the samples before and after KEMS (below melting point) were analyzed by inductively coupled plasma - optical emission 
spectroscopy (ICP-OES) at NSL Labs, Cleveland, OH. The compositions of the olivine sample after KEMS (above melting point) were measured by wavelength dispersive (WDS) electron probe microanalysis (EPMA) with a JEOL JXA-8200 (JEOL Ltda, Tokyo, Japan) WD/ED combined microanalyzer instrument at accelerating voltage of $15 \mathrm{kV}$, beam current of $30 \mathrm{nA}$ and spot size of $0.06 \mu \mathrm{m}$. Sample homogeneity was analyzed by back-scattered electron images. For microprobe analysis, the samples were mounted in epoxy mounts, polished and carbon-coated. An olivine mineral standard (O - 44.03, $\mathrm{Mg}-31.10, \mathrm{Si}-19.56, \mathrm{Mn}-0.09, \mathrm{Fe}-5.06, \mathrm{Ni}-0.16$, numbers in wt \%) (SPI Supplies / structure Probe Inc., West Chester, PA), Al, Cr, Mn, Co, Ni, Ir and $\mathrm{CaMoO}_{4}(\mathrm{Ca}-20.038, \mathrm{Mo}-47.965, \mathrm{O}-31.997$, numbers in wt \%) (C. M. Taylor Company, San Jose, CA) were used in the analyses as standards. The sample compositions were calculated from an average of $\sim 30$ data points.

The as-received olivine sample analyzed by powder XRD followed by whole pattern fitting of its pattern (Rietveld refinement using Topas software) (Fig. S1 and Table S1) is $88.5 \pm 0.2 \%$ forsterite-rich olivine, $6.4 \pm 0.1 \%$ enstatite, $3.5 \pm 0.2 \%$ clinochlore, $0.80 \pm 0.06 \%$ sapphirine and $0.79 \pm 0.04 \%$ quartz. The content of magnesium or forsterite in the solid solution $\left(\mathrm{Mg}_{\mathrm{x}} \mathrm{Fe}_{1-}\right.$ $\left.{ }_{x}\right)_{2} \mathrm{SiO}_{4}$ was derived in two ways: (1) from ICP-OES, which gave $93 \pm 5 \mathrm{~mol} \% \mathrm{Mg}_{2} \mathrm{SiO}_{4}$, i.e., $\mathrm{Fo}_{93 \pm 5}$, and (2) from the linear relation of $\mathrm{d}_{130}$ (Forsterite mole $(\%)=4233.91-1494.59 \mathrm{~d}_{130}$; $\left.d_{130}=\left(c^{-2}+9 b^{-2}\right)^{-0.5}\right)$ (Yoder and Sahama 1957) (lattice parameters $c$ and $b$ are given in Table S1) throughout the composition range of olivine, which gave $94.33 \pm 0.04 \mathrm{~mol} \% \mathrm{Mg}_{2} \mathrm{SiO}_{4}$, i.e., Fo94.33+0.04. The two values are statistically indistinguishable. Besides magnesium and iron, other elements can also be present in minor amounts in the olivine phase (Liebau 2012) or be present in the secondary phases. Although the most intense diffraction peaks of the main phase is attributed to the forsterite $\mathrm{Mg}_{2} \mathrm{SiO}_{4}$ crystal structure, other divalent cations, particulary $\mathrm{Ca}^{2+}$, $\mathrm{Mn}^{2+}, \mathrm{Cr}^{2+}$ and $\mathrm{Ni}^{2+}$, can replace $\mathrm{Mg}^{2+}$ or $\mathrm{Fe}^{2+}$ in the octahedral sites of its solid solution (Liebau 2012). Trivalent aluminum and chromium can replace magnesium and iron in the olivine solid solution by charge - balanced substitutions such as $\mathrm{xM}^{3+}+2 \mathrm{xM}^{3+}=2 \mathrm{x}(\mathrm{Mg}, \mathrm{Fe})^{2+}+(1-\mathrm{x}) \mathrm{Si}^{4+}$ (Liebau 2012). Sodium and scandium are present in the sample as impurities $(>0.01 \%)$; they might be incorporated in the solid solution or $\mathrm{Sc}$ may be present as its binary oxide $\left(\mathrm{Na}_{2} \mathrm{O}\right.$ is unstable and does not occur naturally). 
The olivine sample underwent a weight loss of $\sim 1 \%$ on heating to $1700 \mathrm{~K}$ in vacuum. This weight loss is attributed to decomposition of the secondary phases, mainly clinochlore, since only single phase forsterite-rich olivine was observed by XRD (Fig. S2A) in the sample after it was heat treated at $1853 \mathrm{~K}$ for $10 \mathrm{~h}$ in vacuum before the KEMS experiments. Note that most of cations present in the secondary phases can replace magnesium and iron in the olivine solid solution. The whole pattern fitting (Rietveld refinement using Jade 2010 v.3 software) of the powder XRD patterns of the olivine samples before and after the KEMS experiments are shown in Fig. S2B and S2C. The whole pattern fitting of the powder XRD patterns of the reference samples MgO (periclase PDF card \# 04-013-2667, space group Fm-3m), FeO/Fe (wüstite PDF card \# 04-002-8158, space group Fm-3m; ferrite PDF card \# 98-000-1720, space group Im3m) and $\mathrm{SiO}_{2}$ (cristobalite PDF card \# 00-039-1425, space group P41212) after KEMS are shown in Fig. S3. The final refinements of the XRD patterns of $\mathrm{FeO} / \mathrm{Fe}, \mathrm{MgO}$ and $\mathrm{SiO}_{2}$ using $\mathrm{Jade}$ software yielded $\mathrm{R}=0.54 \%, 4.0 \%$ and $5.89 \%$, respectively. The forsterite content in the olivine samples calculated from their lattice parameters are shown in Table S2. For the experiments performed below the melting point (solidus) of olivine, the content of forsterite increased by $1.05 \pm 0.03$ mole \% in olivine after KEMS. The contents of forsterite in the samples calculated from XRD analysis corroborates well with the forsterite contents calculated from their chemical composition analyzed by ICP-OES and EPMA although the uncertainties for the former analytical technique are in the range of 5\%. No additional phases were detected by powder XRD analysis (Figure S2B) in the sample after the KEMS experiment that was performed below the melting point of olivine. However, additional phases were found in the sample heated above the solidus. XRD analysis (Figure S2C) of this sample showed it was composed of forsterite-rich olivine $(84.9 \pm 0.8 \%)$ and $15.1 \pm 0.3 \%$ protoenstatite $\left(\mathrm{MgSiO}_{3}, \mathrm{PDF}\right.$ card \# 04-007-8621, space group Pbcn).

\section{Selection of the Knudsen Cell Material}

A study of the possible interactions of the cell material with the olivine sample was perfomed since oxides and particularly silicates are highly reactive at high temperatures. Reactivity is usually indicated by a change in starting material composition and/or an inability to reach constant vapor pressures with time. Molydenum, rhenium and iridium cell materials were examined for reaction at temperatures of $1869 \mathrm{~K}, 1863 \mathrm{~K}$ and $1890 \mathrm{~K}$, respectively. The first cell 
material examined was molybdenum since it is inexpensive and relatively easy to machine. Although the ion intensities of the vapor species reached constant values after aproximately 6 hours, the XRD analysis using Rietveld refinement of the sample after KEMS revelealed $0.56 \pm$ $0.02 \%$ of $\mathrm{MoO}_{2}$ (tugarinovite) and $4.5 \pm 0.3 \%$ of $\mathrm{MgSiO}_{3}$ (protoenstatite) as secondary phases. Also $0.04 \pm 0.02 \%$ of molybdenum was detected by ICP-OES in the sample after KEMS. Furthermore, a grayish color was noticed in the sample after KEMS. The rhenium cell material reacted with the sample as indicated by strong variations of the ion intensites of vapor species with time. Even after $16 \mathrm{~h}$ of the Knudsen isothermal experiment with the rhenium cell, the ion intensities had not reached constant values, indicating a reaction with olivine.

Iridium appeared to be the least reactive of the cell materials tested. Other investigators have successfully used Ir to contain reactive oxides (Hilpert 1991, Stolyarova and Semenov 1994). In our case, only pure forsterite was detected by XRD analysis in the sample after KEMS using the iridium cell material. The ion intensities of the vapor species reached constant values after approximately $5 \mathrm{~h}$ of the Knudsen isothermal experiment. Iridium was not detected by ICP-OES analysis in the samples after KEMS. Furthermore, no other phases, beyond those present in the sample before KEMS, were detected by XRD (Fig. S2B) in the sample after KEMS. At high temperatures, no material combinations are truly non-reactive and the molten $\mathrm{MgO}$-rich olvine apparently etched the grain boundaries and attacked iridium above the melting point. The focus of these studies is below the melting point of olivine and iridium appeared to be the best choice for the cell material.

\section{References}

Goldschmidt, V.M. (1938). “Olivine and Forsterite Refractories in Europe.” Industrial \& Engineering Chemistry 30(1): 32-34.

Hilpert, K. (1991). “High-temperature Mass Spectrometry in Materials Research.” Rapid Communication in Mass Spectrometry 8: 175-187. 
Liebau, F. (2012). Structural Chemistry of Silicates: Structure, Bonding, and Classification Springer Science \& Business Media.

Stolyarova V. L. and G. A. Semenov (1994). Mass Spectrometric Study of the Vaporization of Oxide Systems, John Wiley \& Sons, Chicester.

Yoder, H. and T. G. Sahama (1957). "Olivine X-ray Determinative Curve." American Mineralogist 42: 475-491. 